\title{
Characterization of a glacial paleo-outburst flood using high-resolution 3-D seismic data: Bjørnelva River Valley, SW Barents Sea
}

\section{Article}

*Present address: Institute for Energy Technology (IFE), Instituttveien 18, N-0227 Kjeller, Norway.

**Present address: Ruden AS, Oslo Science Park, Gaustadalleen 21, N-0349 Oslo, Norway.

Cite this article: Bellwald $\mathrm{B}$, Planke $\mathrm{S}$, Polteau S, Lebedeva-Ivanova N, Faleide JI, Morris SM, Morse S, Castelltort S (2021). Characterization of a glacial paleo-outburst flood using highresolution 3-D seismic data: Bjørnelva River Valley, SW Barents Sea. Journal of Glaciology 67(263), 404-420. https://doi.org/10.1017/ jog.2020.115

Received: 16 April 2020

Revised: 15 December 2020

Accepted: 16 December 2020

First published online: 22 January 2021

\section{Key words:}

Arctic glaciology; climate change; fluvial transport; glacier hydrology; Jökulhlaups (GLOFs)

\section{Author for correspondence:}

Benjamin Bellwald, E-mail: benjamin@vbpr.no
B. Bellwald ${ }^{1}$, S. Planke ${ }^{1,2,3}$, S. Polteau ${ }^{1, \star}$, N. Lebedeva-Ivanova ${ }^{1}$, J.I. Faleide ${ }^{2,3}$, S.M. Morris ${ }^{1, \star \star}$ (D), S. Morse ${ }^{4}$ and S. Castelltort ${ }^{5}$

${ }^{1}$ Volcanic Basin Petroleum Research AS (VBPR), Høienhald, Blindernveien 5, N-0361, Oslo, Norway; ${ }^{2}$ Centre for Earth Evolution and Dynamics (CEED), University of Oslo, Sem Sælands vei 1, N-0371, Oslo, Norway; ${ }^{3}$ Research Centre for Arctic Petroleum Exploration (ARCEx), The Arctic University of Norway, N-9037, Tromsø, Norway; ${ }^{4}$ Lyme Bay Consulting, 17 Hanover Square, W1S 1BN, London, UK and ${ }^{5}$ Département des Sciences de la Terre, Université de Genève, Rue des Maraîchers 13, CH-1205, Genève, Switzerland

\section{Abstract}

Proglacial braided river systems discharge large volumes of meltwater from ice sheets and transport coarse-grained sediments from the glaciated areas to the oceans. Here, we test the hypothesis if high-energy hydrological events can leave distinctive signatures in the sedimentary record of braided river systems. We characterize the morphology and infer a mode of formation of a $25 \mathrm{~km}$ long and 1-3 km wide Early Pleistocene incised valley recently imaged in 3-D seismic data in the Hoop area, SW Barents Sea. The fluvial system, named Bjørnelva River Valley, carved $20 \mathrm{~m}$ deep channels into Lower Cretaceous bedrock at a glacial paleo-surface and deposited 28 channel bars along a paleo-slope gradient of $\sim 0.64 \mathrm{~m} \mathrm{~km}^{-1}$. The landform morphologies and position relative to the paleo-surface support that Bjørnelva River Valley was formed in the proglacial domain of the Barents Sea Ice Sheet. Based on valley width and valley depth, we suggest that Bjørnelva River Valley represents a braided river system fed by violent outburst floods from a glacial lake, with estimated outburst discharges of $\sim 160000 \mathrm{~m}^{3} \mathrm{~s}^{-1}$. The morphological configuration of Bjørnelva River Valley can inform geohazard assessments in areas at risk of outburst flooding today and is an analogue for landscapes evolving in areas currently covered by the Greenland and Antarctic ice sheets.

\section{Introduction}

The large amounts of fresh water released from today's retreating ice sheets contribute to the global rise in sea level and affect ocean circulations and climate patterns (Richardson and Reynolds, 2000; Teller and others, 2002; Lewis and others, 2006). Locally, meltwater can be stored in dammed proglacial lakes that can be suddenly released forming catastrophic floods with effects to be felt several hundreds of kilometers downstream (Carrivick and Tweed, 2013; Harrison and others, 2018; O'Connor and others, 2020). These outbursts are so violent that they can reshape landscapes (Alho and others, 2005) by carving several tens of meters into the bedrock (Lewis and others, 2006; Gupta and others, 2007; Meinsen and others, 2011; Høgaas and Longva, 2016), and redepositing large amounts of eroded sediments in low-lying areas (Sjogren and Rains, 1995; Murton and others, 2010). Such catastrophic events occurred throughout the Pleistocene deglaciations when huge fluxes of water from the wasting of continental ice sheets created floods of immense magnitude and relatively short duration (Collier and others, 2015; O'Connor and others, 2020). Prehistoric floods related to glacial lake outbursts discharged 100-500 times more water than the largest modern river (Baker, 2002). For example, the outburst of the glacial Lake Agassiz $10 \mathrm{ka}$ ago discharged $10^{14} \mathrm{~m}^{3}$ of water over a 6-month period (Clarke and others, 2004) and the amount of fresh water released into the North Atlantic may have changed ocean circulations leading to a rise in global temperatures (Clark and others, 2001; Teller and others, 2002; Kleiven and others, 2008). Today, the number of these lakes and risks of subsequent outbursts are predicted to increase due to the current global warming trend (Carrivick and Tweed, 2016; Harrison and others, 2018; Shugar and others, 2020). Therefore, the characterization of past outburst events is important to mitigate the risk of these future catastrophic floods, but evidence of their impacts in the geological record is often subtle (Baker, 2002). Here, we use high-resolution 3-D seismic data to test the hypothesis that high-energy hydrological events can leave distinctive signatures in the sedimentary records of braided river systems. We examine if quantitative analyses of paleo-landscapes shaped by outburst flood events can inform geohazard assessments in areas at risk of outburst today.

The aims of this contribution are to determine the ranges in water volumes, slope gradient and discharge velocity necessary to form the Bjørnelva River Valley drainage system, an Early Pleistocene valley preserved on top of a major glacial unconformity in the SW Barents Sea and imaged in high-resolution 3-D seismic data. Our strategy is to characterize the shape and map the distribution of features within Bjørnelva River Valley by applying the concepts of seismic geomorphology. Subsequent classification by analysis of the geometries of these landforms can 
be interpreted in terms of hydrodynamic regime, typically characterized by a set of characteristic geomorphic elements. As such, we will be able to differentiate between glacial drainage systems and depositional environments, and determine if Bjørnelva River Valley is a tunnel valley or a braided river channel belt (Boyd and others, 1988; Piotrowski, 1994; Ó Cofaigh, 1996; Huuse and Lykke-Andersen, 2000; Kelly, 2006; Hammer and others, 2016; Castelltort, 2018). In addition, we characterize the architecture and infill of Bjørnelva River Valley based on attribute analysis of high-resolution 3-D seismic data, which can also be used to distinguish between a subglacial, submarine or subaerial origin.

The recognition of Bjørnelva River Valley is important for understanding the large-scale drainage evolution controlling the transport and deposition of sediments during deglaciation in the Barents Sea. The timing of the valley formation could have had significant paleo-climate implications, in case its outbursts were associated with the delivery of a large pulse of fresh water. The morphological setting of Bjørnelva River Valley could act as a potential analogue for landscapes developing in regions of the melting Greenland and Antarctic ice sheets. Finally, the results from this study can further be used to define safe zones in modern mountainous areas to reduce the number of casualties and damage to infrastructures from such inevitable outbursts (Roberts, 2005; Huss and others, 2007; Baker, 2008; Bajracharya and Mool, 2009; Dussaillant and others, 2010; Carrivick and Tweed, 2016; Harrison and others, 2018; Shugar and others, 2020).

\section{Study area}

The SW Barents Sea is an epicontinental shelf with water depths of 250-500 m (Fig. 1a) and dominated by northeast-southwest to north-south trending faults (Collanega and others, 2017). Butt and others (2002) inferred by numerical modelling that the Barents Sea was a subaerial platform in the earliest Late Pliocene and became a submarine platform in the middle Pleistocene, $\sim 1 \mathrm{Ma}$ ago. The Barents Sea Ice Sheet developed to a moderate size from 2.4 to $1.0 \mathrm{Ma}$, when the Barents Sea was subaerially exposed and became characterized by large-scale glaciations in a submerged environment after $1 \mathrm{Ma}$ (Sejrup and others, 2005; Knies and others, 2009). The pre-glacial topography of the region has been intensively eroded during the Pleistocene (Laberg and others, 2010), when ice streams were flowing in a northeast-southwest to east-west direction (Fig. 1a) (Patton and others, 2016; Piasecka and others, 2016). Modelling shows that, depending on location, between 10 and $1000 \mathrm{~m}$ of pre-Quaternary sequences were eroded in the Barents Sea, with a subsequent glacio-isostatic uplift of $800 \mathrm{~m}$ during the last million years (Fjeldskaar and Amantov, 2018). Glacio-erosive processes at the base of the former Barents Sea ice streams transported sediments from the continental shelf to the Bjørnøyrenna Trough Mouth Fan, which comprises a volume of $\sim 670000 \mathrm{~km}^{3}$ (Fig. 1a) (Vorren and others, 1991; Laberg and Vorren, 1996). The Arctic has warmed dramatically in recent decades, with highest temperature increases observed in the northern Barents Sea (Carmarck and others, 2015). Sea ice covers the Barents Sea seasonally, but most areas are sea-ice-free during the summers (Lind and others, 2018).

Our study area is located in the Hoop area where the Hoop Fault Complex is the most prominent structural element. The Hoop Fault Complex is surrounded by the Bjarmeland Platform to the west and north, the Mercurius High to the east and the Maud Basin to the south (Fig. 1b). The pre-Quaternary geology in the Hoop area is dominated by Cretaceous shales, which are an easily erodible material (Henriksen and others, 2011; Ktenas and others, 2019) (Fig. 1b). The Loppa High and the Fedynsky High are the most prominent Cretaceous highs in the SW Barents Sea (Fig. 1a).
The water depth of the study area varies from 430 to $470 \mathrm{~m}$. Repeated glacial erosion formed the Upper Regional Unconformity (URU), which is buried under 20-65 m of glacial sediments in the study area and well-imaged in seismic data (Bellwald and others, 2018a) (Fig. 2a). The formation of glacial landforms at the URU level was controlled by Pleistocene ice streams (Piasecka and others, 2016) that scarped the bedrock to form mega-scale glacial lineations and hill-hole pairs (Fig. 2b). The URU is directly draped by a negative-amplitude reflection in some parts of the study area (Bellwald and Planke, 2018), but where the URU deeply cuts into Lower Cretaceous sediments several meters of sediments are present between the URU and this reflection (Fig. 2a). The URU is an amalgamated erosional surface and the landforms identified at the URU provide Pleistocene analogues to present-day processes and climate changes (Tasianas and others, 2018; Bellwald and others, 2019). These landforms include mega-scale glacial lineations indicative of grounded ice, hill-hole pairs and depressions indicative of gas-hydrate melting and pockmarks indicative of fluid escape.

Shackleton and others (2018) modelled the development of subglacial lakes and subglacial drainage networks beneath the Fennoscandian and Barents Sea ice sheets over the last glaciation, with up to 3500 potential subglacial lakes. Meltwater-related landforms have previously been mapped along the present seabed of the Barents Sea using bathymetric data (Bjarnadóttir and others, 2017; Newton and Huuse, 2017). Here we show that fluvial landforms can be imaged along the URU horizon beneath $65 \mathrm{~m}$ of glacial sediments using high-resolution 3-D seismic data (Fig. 2). We suggest that this channel belt and associated incised valley was generated by a fluvial system, named here as the Bjørnelva River Valley, Norwegian for Bear River Valley.

The SW Barents Sea is a suitable place to test if high-energy hydrological events can leave distinctive signatures in the sedimentary record of braided river systems, because of (i) a flat paleo-surface with preserved landforms, (ii) its well-established Pleistocene glacial history, (iii) its subaerial exposure until $1 \mathrm{Ma}$ and (iv) high-quality 3-D seismic data available over extended areas.

\section{Data and methods}

This study comprises two conventional and one high-resolution 3-D seismic datasets from the Hoop area in the SW Barents Sea (Figs 1-3). The conventional 3-D seismic surveys A and B cumulatively cover an area of $\sim 13000 \mathrm{~km}^{2}$, but only $600 \mathrm{~km}^{2}$ are used for this study. These surveys have a vertical resolution of $\sim 12 \mathrm{~m}$ and bin sizes of $25 \mathrm{~m} \times 12.5 \mathrm{~m}$ (Survey A) and $18.75 \mathrm{~m} \times 12.5 \mathrm{~m}$ (Survey B) (Figs 2, 2b, 3a). The high-resolution P-Cable 3-D seismic survey HR14 covers $\sim 30 \mathrm{~km}^{2}$ (Fig. $2 \mathrm{~b}$ ) with a bin size of $6.25 \mathrm{~m} \times 4.75 \mathrm{~m}$. The maximum frequency of the seismic signal of $\sim 300 \mathrm{~Hz}$ at URU depths allows a vertical resolution of 1-2 m for HR14 (Lebedeva-Ivanova and others, 2018). Therefore, the P-Cable 3-D seismic data provide crisper imaging of the URU surface (Fig. 3b) than the conventional 3-D seismic data (Fig. 3a) and permit the study of the geomorphology, deposits and origin of the channel system.

Three-dimensional seismic data have given birth to the discipline of seismic geomorphology, which is described by Posamentier and others (2007) as 'the application of analytical techniques pertaining to the study of landforms and to the analysis of ancient, buried geomorphological surfaces as imaged by 3D seismic data.' Glacio-fluvial seismic geomorphology is defined here as the study of glaciofluvial systems (deposits and processes) using 3-D seismic images in map view. Applying the concept of seismic geomorphology allows to examine paleo-landscapes and to characterize geological features (Posamentier, 2001; Darmadi and others, 2007; Planke and others, 2017; Bellwald and others, 


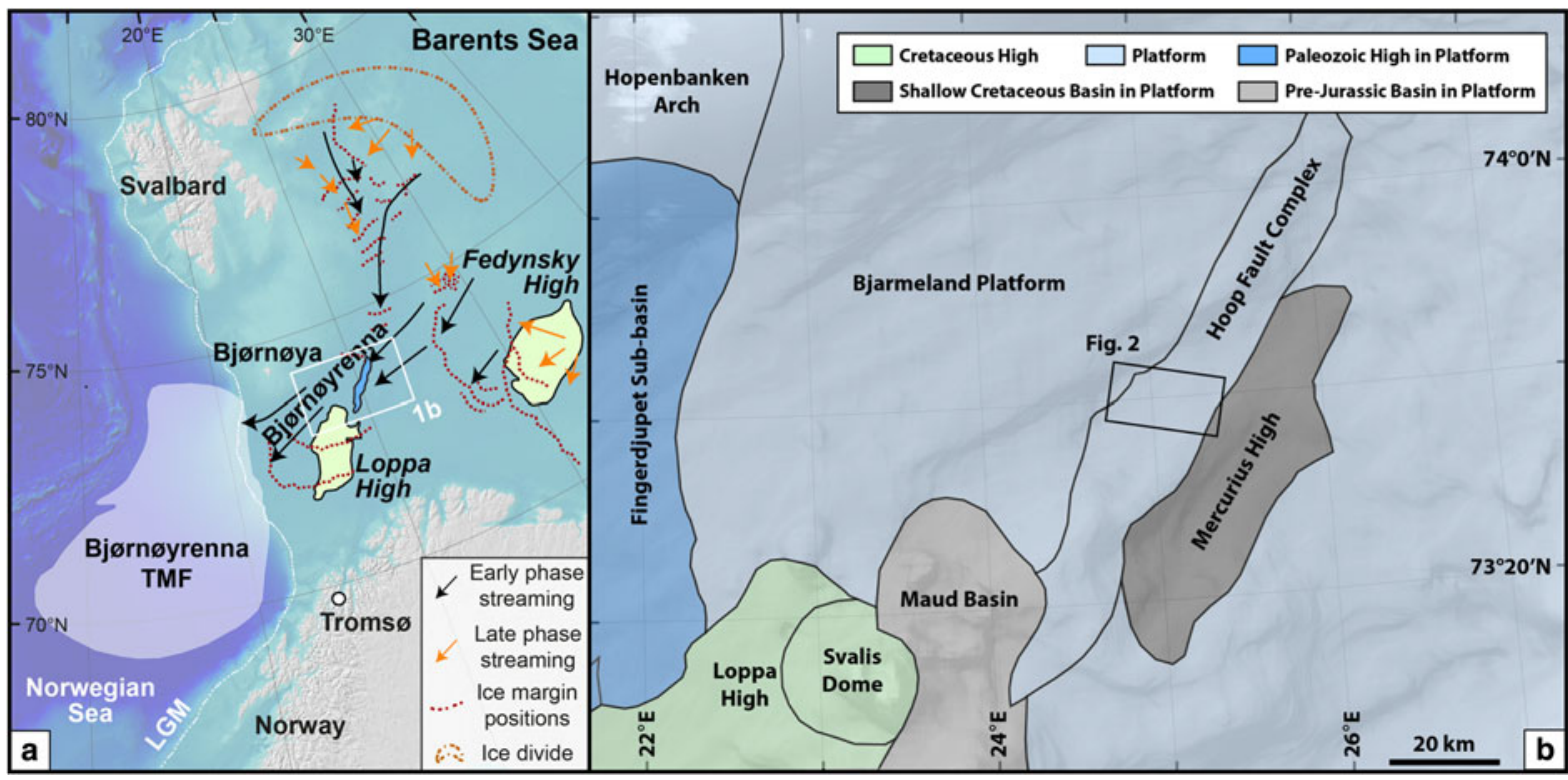

Fig. 1. Geological setting of the SW Barents Sea. (a) Main ice-streaming phases of the Western Barents Sea. Cretaceous highs (light green) and Hoop Fault Complex (blue polygon) are shown. The maximum extension of the Barents Sea Ice Sheet during the Last Glacial Maximum (LGM) is marked as white line (Svendsen and others, 2004). Arrows indicate previously inferred major ice stream directions (Andreassen and Winsborrow, 2009; Bjarnadóttir and others, 2013; Rüther and others, 2013). Ice margin positions (Winsborrow and others, 2010; Bjarnadóttir and others, 2013; Rüther and others, 2013) and ice divides (Ottesen and others, 2005) are indicated (red dashed lines). TMF: Trough mouth fan. (b) Tectonostratigraphic setting of the Hoop area. Geological elements are displayed above gray-shaded seafloor. Extent is shown in (a).

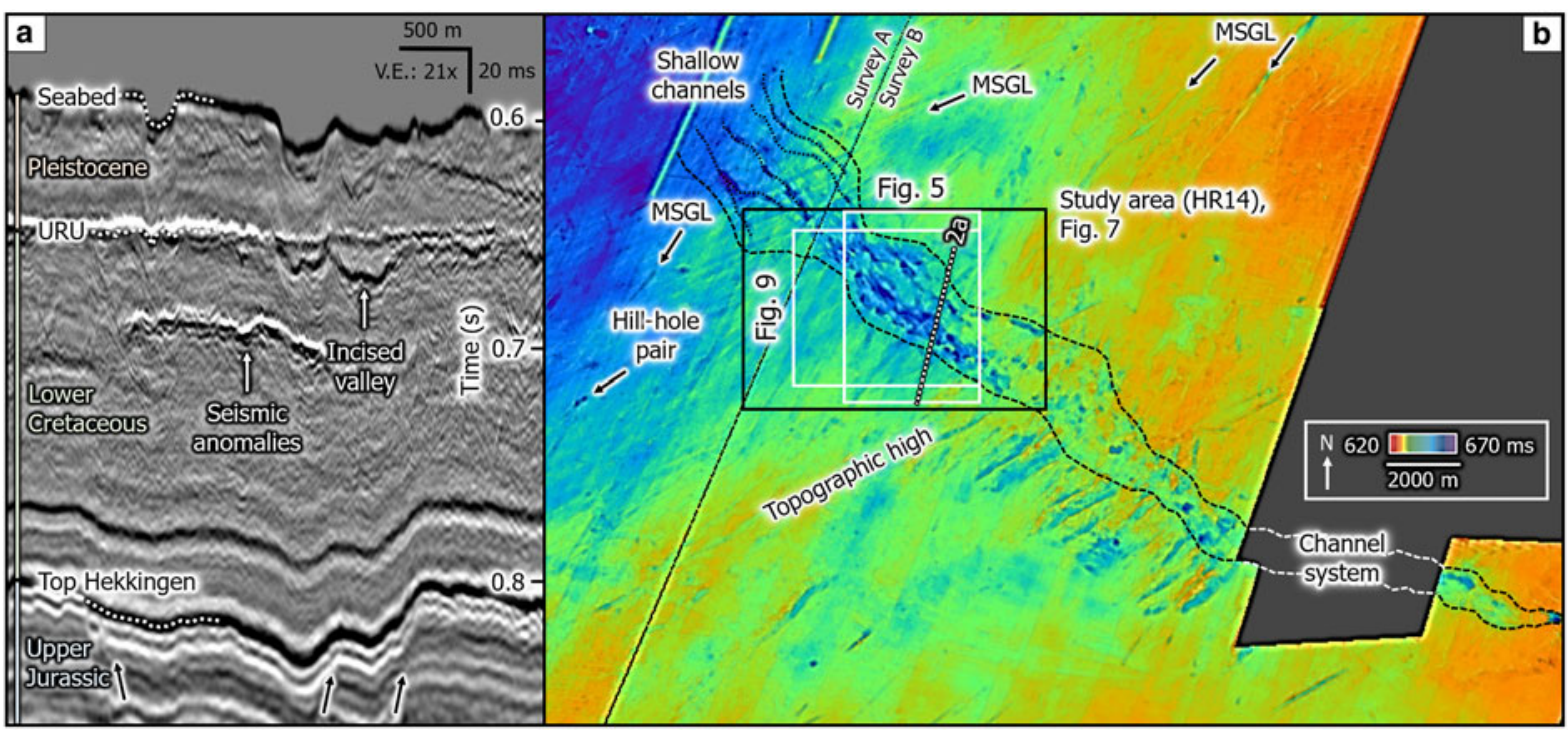

Fig. 2. Study area. (a) High-resolution seismic profile showing the stratigraphy of the shallow subsurface of the Hoop area. Deeper faults are indicated by black arrows. Profile location is shown in (b). (b) URU structure map of the study area (Hoop area) generated by interpretations of conventional 3-D seismic data (Survey $A$ and B, figure shows the extent of the cubes only partly). Extent of channel system (black stippled line) and P-Cable 3-D seismic coverage (black box, HR14, seismic data used in this study) are indicated. MSGL: Mega-scale glacial lineation.

2019). Even if geological landscapes imaged by $3-\mathrm{D}$ seismic data seem to occasionally express fossilized processes, the interpreted surface of this study (URU) is an amalgamated surface and can include expressions shaped by successive processes during different time intervals.

Here we can interpret with high confidence the fluvial landforms and channel infill of Bjørnelva River Valley using meter-scale vertical and horizontal resolutions in the seismic data (Fig. 3). This geomorphological interpretation is completed by a comparison of interpreted landforms and Earth surface analogues (satellite imagery) to demonstrate the fluvial nature of the interpreted seismic landforms.
In the conventional 3-D seismic surveys, the URU interpretation relied on manually correcting the auto-tracked horizon of the most prominent reflection $<100 \mathrm{~m}$ below the seabed. As the URU horizon is defined by a continuous reflection with high amplitudes in the conventional seismic data, auto-tracking was successful for most of the dataset. The resulting URU grid defines the extent of the channel system with a horizontal resolution of $12.5 \mathrm{~m}$ at best (Fig. 3a). Details in the fluvial landforms and the channel infill can only be imaged using high-resolution 3-D seismic data and mapping of these details is critical for a geomorphological analysis. Increased vertical and horizontal resolutions in the HR14 data allowed a meter-scale interpretation of the channel 


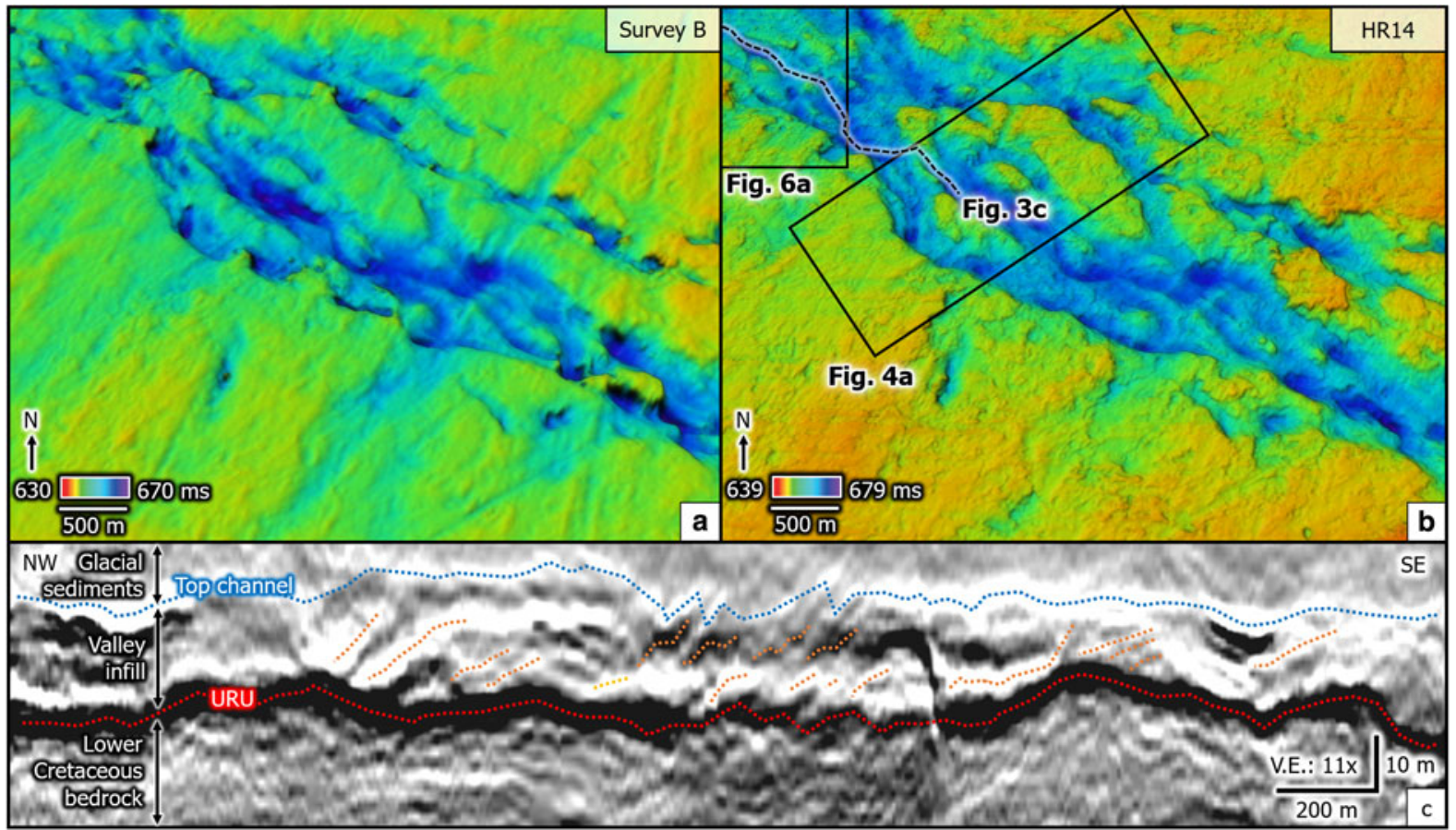

Fig. 3. Bjørnelva River Valley and channel belt. (a) URU surface generated by conventional 3-D seismic data with bin sizes of $18.75 \mathrm{~m} \times 12.5 \mathrm{~m}$ and (b) by highresolution P-Cable 3-D seismic data (HR14) with bin sizes of $6.25 \mathrm{~m} \times 4.75 \mathrm{~m}$. Panels a and b represent the extent of the P-Cable data (see Fig. $2 \mathrm{~b}$ ). (c) P-Cable 3-D seismic profile showing the seismic stratigraphy. Average dip of $3^{\circ}$ for the northwestwards-dipping accretional channel beds (yellow stippled lines). See panel $b$ for profile location.

infill (Fig. 3c). Two surfaces have been interpreted in the HR14 data: (i) the URU defined as a continuous high-amplitude positive reflection and (ii) the Top channel defined as a discontinuous medium-amplitude negative reflection (Fig. 3c). Every eighth inline of the HR14 data (corresponding to a spacing of $50 \mathrm{~m}$ ) has been interpreted by manual picking in the Kingdom Software and both horizons were subsequently interpolated into grids. The grids were snapped to a horizon and the maximum seismic amplitude of a vertical window of $4 \mathrm{~ms}$ along the snapped horizon has been used to interpret the seismic geomorphology of the channel system. The grids generated from interpreting HR14 data have a horizontal resolution of 5-6 m. The Apollo well, located $\sim 40 \mathrm{~km}$ northwest of the study site, was used to constrain P-wave velocities that vary between 1800 and $2000 \mathrm{~m} \mathrm{~s}^{-1}$ in the glacial sediments (www.npd.no, 2018). Seismic velocities of $1500 \mathrm{~m} \mathrm{~s}^{-1}$ for the water column and $1900 \mathrm{~m} \mathrm{~s}^{-1}$ for glacial sediments were used for converting two-way travel time to depth in our study.

The base of the valley is interpreted using structure maps and the peak seismic amplitude of the URU pick. The thickness of the valley infill is defined by subtracting the Top channel reflection from the URU reflection (Fig. 3c). The sum of the seismic amplitudes of the valley infill has been used to conclude the type of infill deposits. The number of Z-crossings, the locations where the seismic signal of a seismic trace changes polarity, was used to image sequence variations in the valley infill succession.

We mapped and measured the geometries of 28 channel bars identified in HR14. The bar length is defined as the longest axis of a bar and the bar width is measured as the widest part of the bar perpendicularly to the bar length. The bar length and bar width of these channel bars are then compared to a global river bar database (Church and Rood, 1983) and to a dataset of bars in braided rivers identified on GoogleEarth (Castelltort, 2018). This comparison provides estimates on the paleo-slope gradients and the grain sizes of the valley infill. There is no existing statistical dataset that allows us to compare the channel bars against landscapes that were eroded by catastrophic Quaternary floods.
The average flow velocity $\left(v_{\mathrm{m}}\right)$ of a river is based on the hydraulic radius $(R$, in $\mathrm{m})$ and valley slope $\left(I\right.$, in $\left.\mathrm{m} \mathrm{m}^{-1}\right)$, and is calculated using empirical equations (e.g. Duller and others, 2012). The hydraulic radius is in wide and flat cross-sections approximately the valley depth $(H)$, so we assume $R \sim H$. The average flow velocity $v_{m}$ can approximately be calculated using the Gauckler-Manning-Strickler equation:

$$
v_{m}=\frac{1}{n} \cdot R^{2 / 3} \times I^{1 / 2}
$$

where $n$ is Mannings roughness coefficient $(\sim 0.03)$. The river discharge is calculated using the average flow velocity multiplied by the cross-sectional area of the portion of the valley occupied by the flow. However, we note that this paleo-hydraulic analysis is a rather simplistic estimation. Despite any evidence, we assumed the valley depth and water depth to be equal, and hence our paleo-hydraulic analysis is a simple and conservative estimation for a single flow regime.

\section{Results}

\subsection{Seismic geomorphology}

Multiple sets of mega-scale glacial lineations and hill-hole pairs, indicating different ice flow directions, are identified at the URU in conventional 3-D seismic data in the Bjørnøyrenna area (Fig. 2b). These landforms have been analyzed in previous publications (Piasecka and others, 2016; Bellwald and others, 2019). The most striking structure imaged on the URU in the study area is a $\sim 25 \mathrm{~km}$ long, southeast-northwest oriented channel belt system within an incised valley (Fig. 3a). The system displays a characteristic braided geometry and increases in width from $\sim 1 \mathrm{~km}$ in the southeast to $>3 \mathrm{~km}$ in the northwest. The incised valley which contains this channel belt has margin slopes ranging from $20^{\circ}$ to $60^{\circ}$. The overall gradient of the channel system is $2.5 \mathrm{~m} \mathrm{~km}^{-1}\left(0.14^{\circ}\right)$ and the longitudinal profiles along individual 
channels can have locally reverse gradients (Fig. 3c). The data show that the channel belt widens and contains several less deeply incised channels in the northwest of the study area (Fig. 2b).

The channel belt has a width of $800-2000 \mathrm{~m}$ in the HR14 area (average width of $1500 \mathrm{~m}$ ) (Figs 3b, 4a) and consists of five 50$300 \mathrm{~m}$ wide channels eroding up to $13-23 \mathrm{~m}$ of underlying Cretaceous sedimentary bedrock (average channel depth of $18 \mathrm{~m}$ ) (Fig. 4b). The depth-to-width ratios observed here vary from $\sim 1: 100$ for the entire channel belt system to 1:20 for individual channels. The geometries of the individual channels are well defined in the seismic profiles and can vary from flat-bottomed and box-shaped to U- and V-shaped troughs (Fig. 4b). The reflections defining the base of the channels are characterized by the highest positive-amplitude reflections (Fig. 5b).

The channels are divided by 28 , southeast-northwestelongated bars, which are 130-1570 $\mathrm{m}$ long, 50-440 $\mathrm{m}$ wide and 2-17 $\mathrm{m}$ high (Figs 4a, 6a, 7). Most of the bars have a lemniscate or teardrop outline, with elongated tips pointing northwestwards. The reflections defining the top of the bars have lower amplitudes when compared to the channels (Fig. 5b) and their seismic facies is characterized by horizontal layering (Fig. 6b). Field examples show that streamlined fluvial landforms can either be built through fluvial deposition or the result of removal of the material around (Collier and others, 2015, and references therein). We suggest the streamlined bars identified in the incised valley to represent fluvial depositional features rather than erosional bedrock remnants, as (i) they are characterized by lower seismic amplitudes at their top compared to the deepest channels and (ii) they have different seismic facies compared to the underlying Cretaceous bedrock (horizontal layering and moderate seismic reflectivity vs low seismic reflectivity). Although depositional islands are documented to be inherently unstable as the channels surrounding them tend to laterally migrate (e.g. Détriché and others, 2010), the sedimentary bars of this study are most likely preserved in the channel belt and represent the last stage of fluvial activity at this level.

\subsection{Analysis of channel geomorphology}

The 28 southeast-northwest-elongated bars (Fig. 7) mapped in the HR14 data have been compared to global databases on modern braided rivers (Fig. 8) (Church and Rood, 1983; van den Berg, 1995; Castelltort, 2018). The average dimensions of the channel bars are $350 \mathrm{~m}$ in length, $150 \mathrm{~m}$ in width and $7 \mathrm{~m}$ in height (8 ms) (Figs 7, 8a; Table 1). Therefore, the bars of the channel system plot within the dimensions of modern braided river bars.

The mean bar elongation can be used to determine the slope gradient based on modern braided river datasets (Castelltort, 2018). Here, a mean bar elongation of $2.54 \pm 0.04$ for the 28 river bars implies a paleo-river gradient of $0.64 \pm 0.1 \mathrm{~m} \mathrm{~km}^{-1}$ (Fig. 8b). The sediments deposited by modern braided rivers flowing along slopes dipping by $0.64 \mathrm{~m} \mathrm{~km}^{-1}$ are in a median grain size of two clusters: a first cluster from $\sim 0.1$ to $1 \mathrm{~mm}$ (i.e. sand) and a second cluster from 10 to $100 \mathrm{~mm}$ (i.e. gravel and pebbles, Fig. 8c).

Compared to the modern river database of Church and Rood (1983), the river characteristics of this study should be consistent with a gently dipping, wide and deep channel belt (Figs $8 \mathrm{~d}-\mathrm{f}$ ). Although the bars of this study are consistent with modern braided rivers, the plots of Church and Rood (1983) indicate that the identified incised valley is an outlier with respect to valley depth and valley width (Figs 8d-f).

We calculated a first order estimation of the average flow velocity to be $6 \mathrm{~m} \mathrm{~s}^{-1}$, corresponding to an average discharge of $160000 \mathrm{~m}^{3} \mathrm{~s}^{-1}$. The average flow velocity, calculated using the Gauckler-Manning-Strickler equation Eqn (1) and the average discharge were determined by using an inclination of
$0.64 \mathrm{~m} \mathrm{~km}^{-1}$, an average water depth (valley depth) of $18 \mathrm{~m}$ and an average valley width of $1500 \mathrm{~m}$.

\subsection{Valley infill}

The channels along the carved bedrock shaping the channel belt system of the incised valley are overlain by the valley infill corresponding to the succession between the Top channel and the URU reflections. The valley infill is characterized by up to $23 \mathrm{~m}$ of horizontal, low-angle dipping and chaotic reflections which downlap and onlap the URU reflection (Figs 3c, 6c, 9c). The infill towards the valley base is more chaotic and consists of discontinuous and scattered seismic reflections (Fig. 4b). The infill of the upper part of the channel deposits displays more continuous seismic reflections, thus indicating sediment layering (Fig. 9c).

The infill is thickest where the channels are deepest (Fig. 5c) and dominated by negative-amplitude reflections (Fig. 9b). The Z-crossing parameter on Figure 10a is the number of times a seismic trace changes polarity and can be used to determine the number of thin homogeneous sedimentary sequences within the infill succession. The signal changes polarity more than six times within the infill in the deepest channels and not more than twice above the channel bars (Fig. 10). The Top channel reflection can be traced over larger areas above the URU (Fig. 4b). The valley-infill reflections dip in a northwestwards direction with an average angle of $\sim 3^{\circ}$ (Fig. 3c), but reflections can also dip perpendicular to individual channels (Fig. 6c) due to lateral aggradation.

\section{Discussion}

The discussion focuses on the formation, the glacial and hydrological configuration, paleo-geographic reconstructions and the sedimentary imprint of the incised valley. We discuss the broader implications of the valley on drainage evolution and climate development. Finally, we compare the outburst event with Pleistocene and historic glacial lake outburst floods and show regions with potential analogies in future.

\subsection{Nature and implications of the URU reflection}

The reflections with the highest seismic amplitudes in the deepest channels (Fig. 5b) indicate a strong impedance contrast, probably representing a lithological contrast at URU between hard bedrock below and soft valley infill above as well as changes in fluid content and geotechnical properties. This hard- to soft-bed abrupt transition indicates that the system carved an up to 23 m-deep and several $\mathrm{km}$-wide valley into Lower Cretaceous bedrock in a subglacial, submarine or subaerial environment. Following the orientation of the deepest channels and teardrop shape of the largest streamlined channel bars, the discharge occurred in a southeast- or northwest-ward direction (Fig. 2b). A widening of the channel belt system and shallowing of individual channels in the northwest of the study area (Fig. 2b) indicate less erosion due to progressively diminishing flow rates and energy in the deepest Bjørnøyrenna (Bear Island Trough). These shallower channels could also represent relicts of originally deeper channels, which underwent increased glacial erosion related to repeated ice-streaming in the deeper Bjørnøyrenna after the formation of the valley (Patton and others, 2016). All this evidence combined with the northwestwards-dipping of sediment infill (Fig. 3c) favor a northwestwards flow direction of the system towards the deeper Bjørnøyrenna (Fig. 1a). The sediment load related to the channel belt formation has probably been transported during subsequent glaciations into the Bjørnøyrenna Trough Mouth Fan (Fig. 1a), where most of the glacio-erosive products of the Barents Sea are redeposited (Laberg and Vorren, 1996). At a 


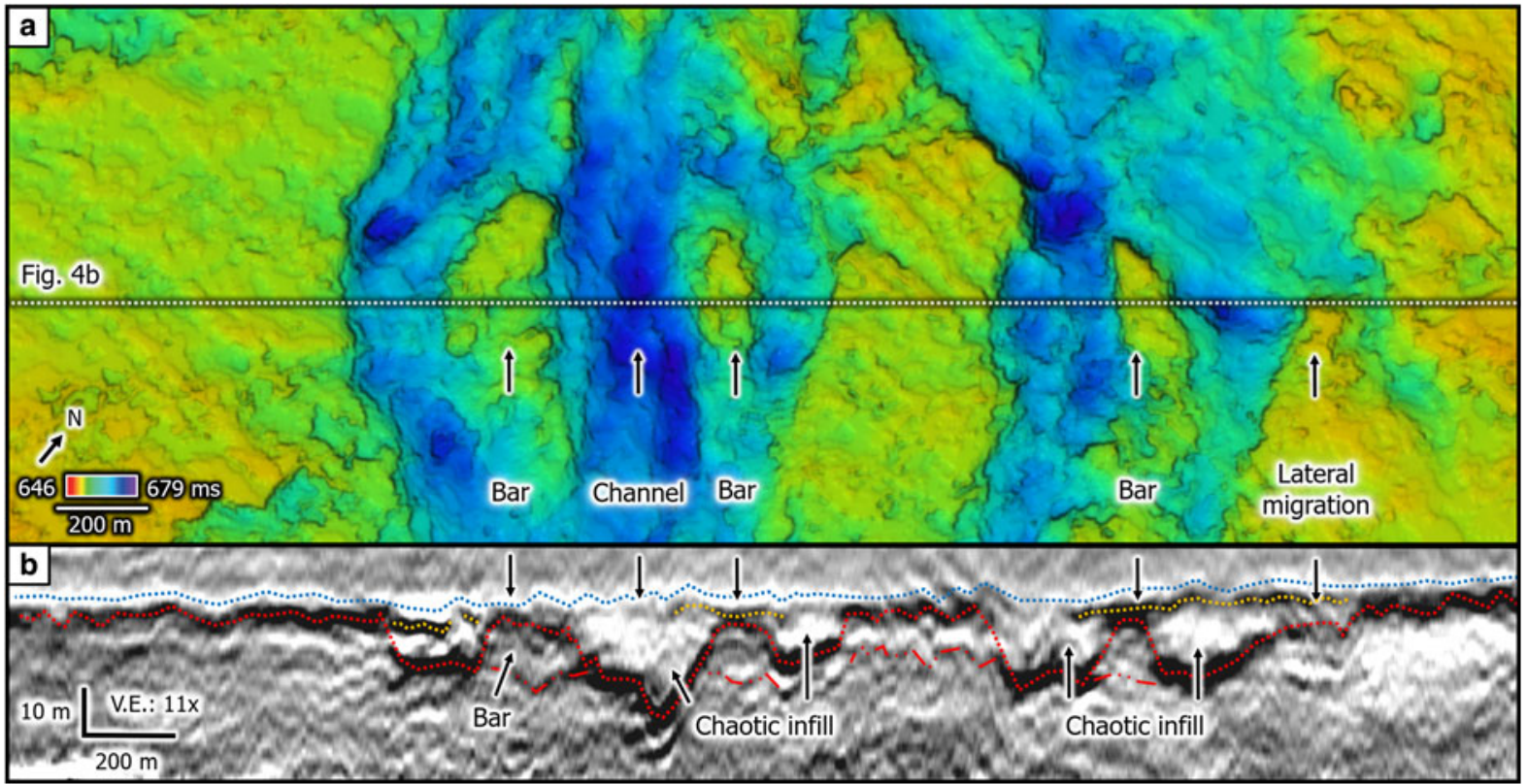

Fig. 4. Seismic architecture of channel system and infill (HR14). (a) Structure map across Bjørnelva River Valley. (b) Seismic profile showing the depositional architecture of the channel belt eroding the URU (red line) and the Top channel reflection draping the channel system (blue line). Acoustically chaotic negative-amplitude reflections at the base of the channel belt infill and acoustically continuous reflections at the top of the channel belt infill (yellow lines) are shown. For map location, see Figure $3 b$.

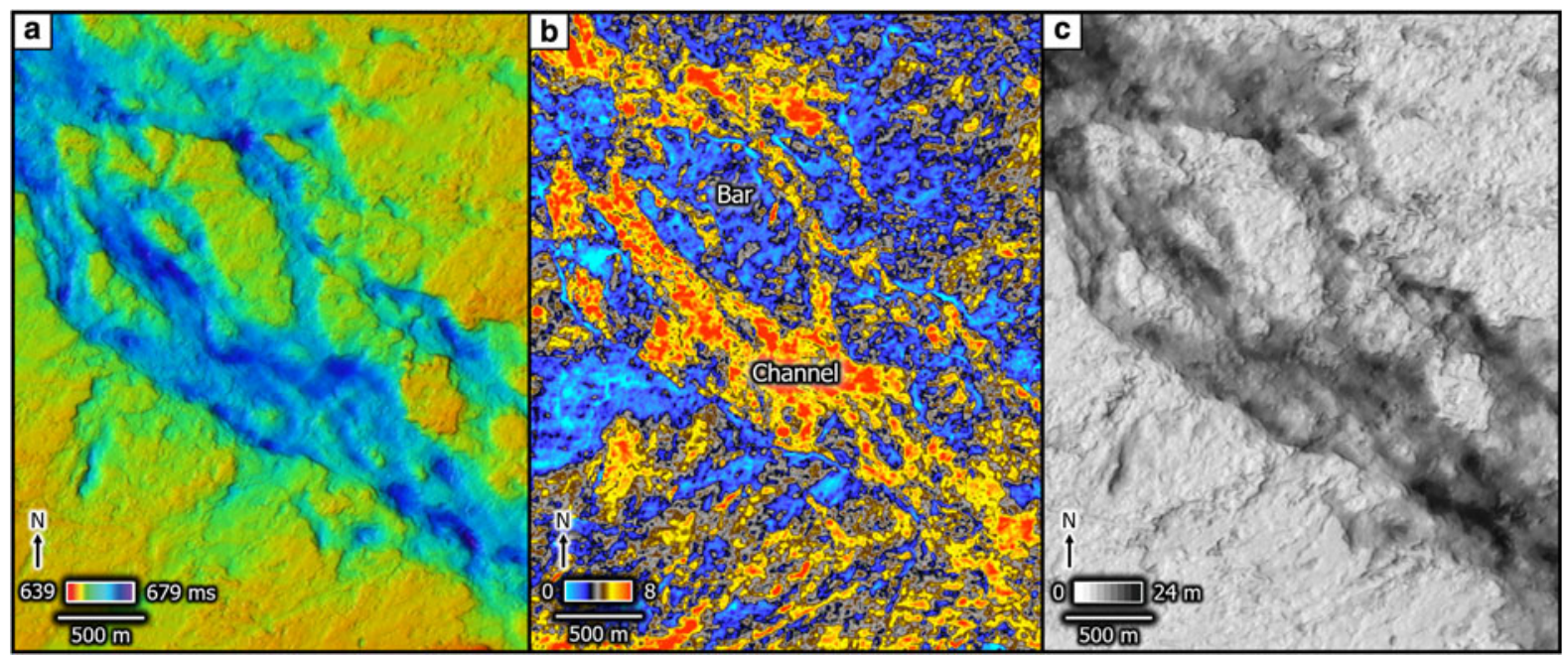

Fig. 5. Seismic geomorphology of the channel belt and bars (HR14). (a) Structure map. (b) Seismic peak amplitude of the URU reflection in a vertical window of $4 \mathrm{~ms}$. Channels are characterized by high amplitudes, whereas bars have low amplitudes. (c) Isopach map of the sediment package in meters between the URU and the Top channel reflection. Location is shown in Figure $2 b$.

local scale, bedrock geology can influence the orientation of channel belts (Booth and Hallet, 1993). The distribution of glacial landforms along the URU has previously been linked to different types of faults (Bellwald and others, 2018b), but here the faults do not appear to influence the course of the channel belt system.

\subsection{Bjørnelva River Valley: a channel belt formed by a braided river}

We interpret the incised valley as a proglacial braided river system consisting of a series of broad and shallow channels, bars and dry islands (Miall, 1977), named here as Bjørnelva River Valley. Braided streams occur in rivers with high slope gradients and/or large sediment load (Schumm and Kahn, 1972) where the main channel can generally be distinguished within the overall braided pattern, although several principal channels may be present in some river sections (Rust, 1972; Bennett and others, 2002). Individual channels are separated by small and often temporary islands called braided bars. Statistical analysis of modern braided bars identified on satellite images show that the bar dimensions are proportional to the river widths (e.g. Kelly, 2006) and have average elongations (length/width ratio) of around five (e.g. Kelly, 2006; Castelltort, 2018). The formation of braided rivers is often linked to highly variable discharge such as flash floods, during which braided bars can develop under high-stage flow conditions and often are reworked and dissected into multiple bars that emerge as flow recedes (Russell and others, 1995; Stott, 2002; Church, 2006).

A subaerial, proglacial origin for Bjørnelva River Valley is supported by the geomorphology, modern river analogues and numerical modelling of the Barents Sea (Figs 8, 11, 12). The geomorphological analysis of the dimensions of the Bjørnelva River 


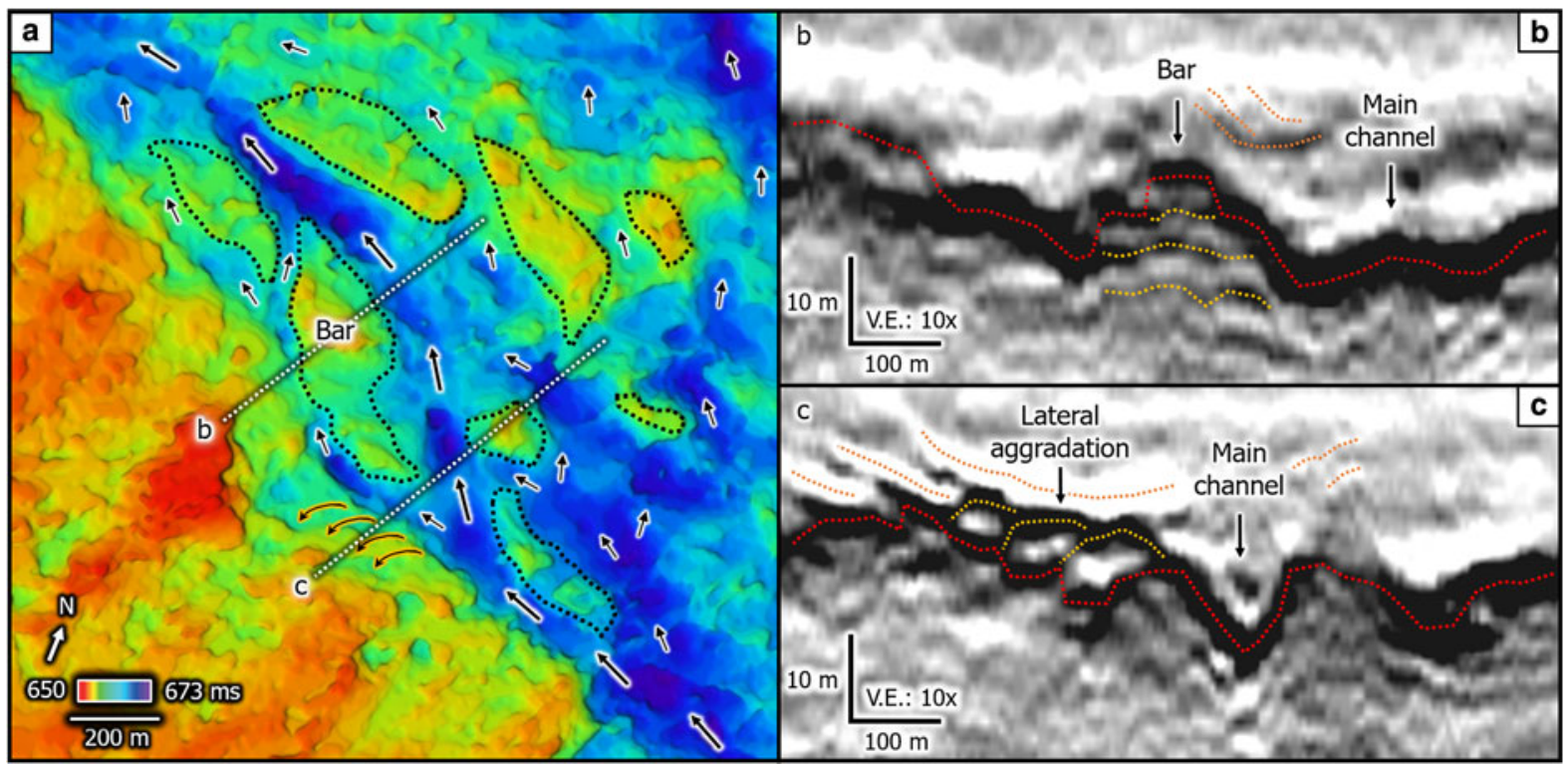

Fig. 6. Seismic architecture of channel belt and bars (HR14). (a) Structure map of channel bars (stippled lines). Main channel is indicated by thick white arrows and other channels are displayed by thin white arrows. Golden arrows show lateral sediment aggradation. (b) Seismic stratigraphy of a channel bar. Parallel layering characterizing the internal structure of the channel bar is indicated by yellow stippled lines. (c) Lateral aggradation of channel infill. Yellow stippled lines indicate westwards aggradation of channel infill from the deepest channel. Red stippled lines in b and c mark the URU. For map location, see Figure $3 \mathrm{~b}$.

Fig. 7. River bar geometries of the 28 identified features on a structure map using HR14 (vertical resolution of 1-2 m, horizontal resolution of $4.75 \mathrm{~m} \times 6.25 \mathrm{~m}$ ). Numbers on the left panel mark bar ID in Table 1. Location is shown in Figure $2 b$.

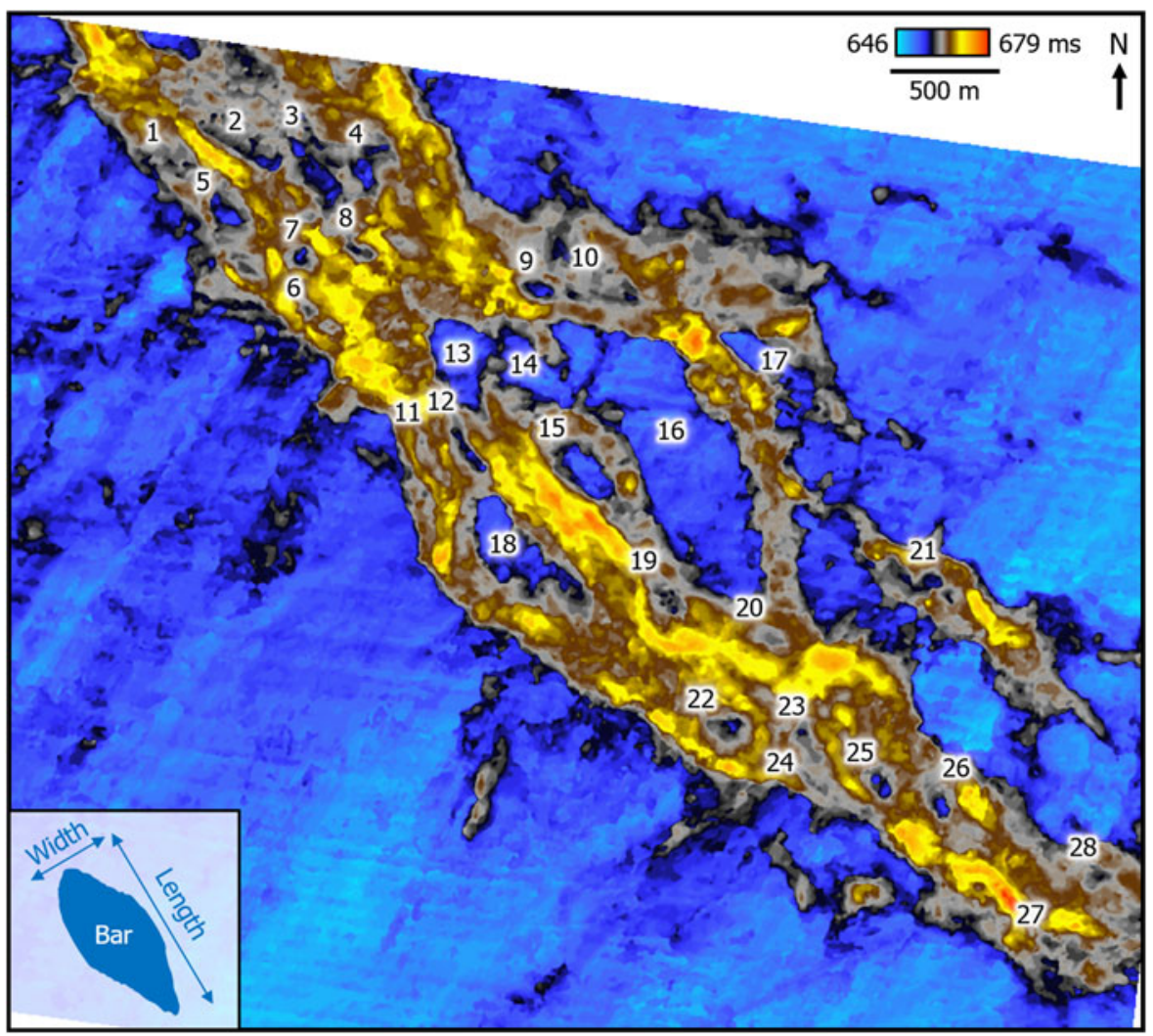

Valley bars shows that they compare with bars of modern braided rivers (Fig. 8). In addition, comparisons of the Bjørnelva River Valley system with satellite images of braided rivers in glaciated terrains display similar landform assemblages in both shape and dimension (Fig. 11). The Whataroa River (South New Zealand) is shown as an example in Figure 11, but the channel belt geometries of the Bjørnelva River Valley fit expressions characteristic for braided rivers all over the world (Fig. 12c) (Castelltort, 2018). Uplift studies of the Western Barents Sea further show that the study area was subaerial in post-Eocene/pre-Quaternary times and evolved into a marine platform $\sim 1 \mathrm{Ma}$ ago (Fig. 12a) (Dimakis and others, 1998; Butt and others, 2002). Thus, the Bjørnelva River Valley is likely to be a relict of a proglacial braided river system from Pleistocene times (Fig. 12b). The magnitude of incision (depth of 13-23 m) fits with observations of modern braided rivers in proglacial environments (Fig. 8d), but not in a subglacial domain where valleys are usually several hundred meters deep. 

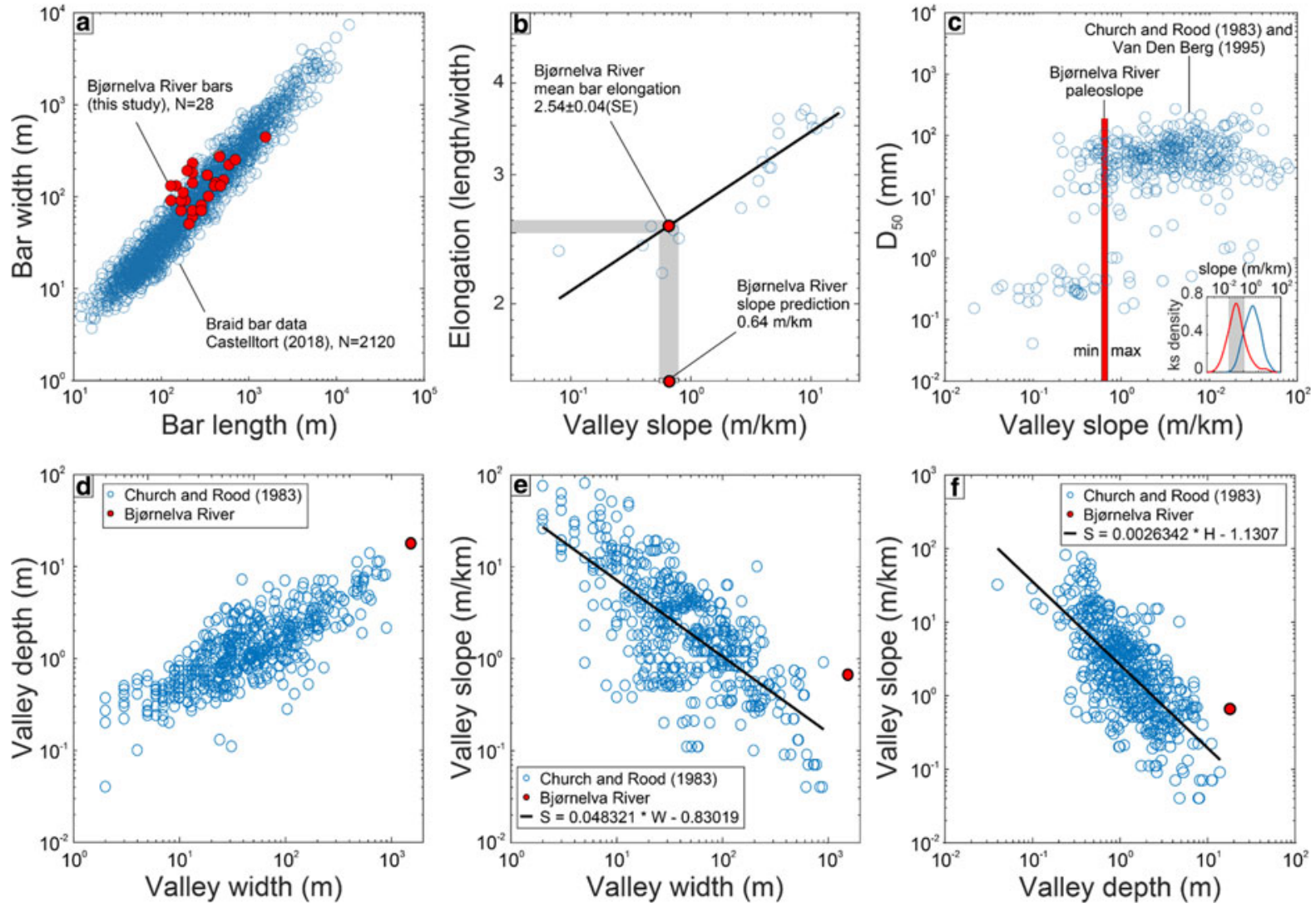

Fig. 8. Comparison of the Bjørnelva River Valley system with modern braided rivers. (a) Width vs length of Bjørnelva River Valley bars from Figure 7 ( $N=28$ ) superimposed on bar dimensions of 22 modern braided rivers ( $N=2120$ bars, Castelltort, 2018). (b) Bar elongation vs valley slope for definition of paleo-slope gradient. A mean bar elongation of 2.54 implies a paleo-slope gradient of $0.64 \mathrm{~m} \mathrm{~km}^{-1}$ for Bjørnelva River Valley. (c) Mean Bjørnelva River Valley slope gradient compared to modern rivers of Church and Rood (1983) and van den Berg (1995) is compatible with grain size of 0.1-1 mm or 10-100 mm. Kernel density (inset) of slope gradient for grain size of $<1 \mathrm{~mm}$ (red) and more than $10 \mathrm{~mm}$ (blue) suggests that the valley infill of river slopes of between 0.1 and $1 \mathrm{~m} \mathrm{~km}^{-1}$ consists mostly of grain sizes of $<1 \mathrm{~mm}$ (red). (d) Correlation between valley width and valley depth. Valley width is defined as the incised valley measured from the edge of the slopes that contain the channel belt within. (e) Correlation between valley width and valley slope. (f) Correlation between valley depth and valley slope. Dataset for a-b from Castelltort (2018) and c-f from Church and Rood (1983).

Table 1. Geometries of the 28 river bars. Bar ID indicates feature identified in Figure 7

\begin{tabular}{|c|c|c|c|c|}
\hline Bar ID & $\begin{array}{c}\text { Length } \\
\mathrm{m}\end{array}$ & $\begin{array}{l}\text { Width } \\
\text { m }\end{array}$ & $\begin{array}{c}\text { Height } \\
\text { ms }\end{array}$ & $\begin{array}{c}\text { Height } \\
\text { m }\end{array}$ \\
\hline 1 & 290 & 70 & 8 & 7.2 \\
\hline 2 & 420 & 140 & 8 & 7.2 \\
\hline 3 & 410 & 130 & 7 & 6.3 \\
\hline 4 & 230 & 230 & 4 & 3.6 \\
\hline 5 & 520 & 150 & 10 & 9 \\
\hline 6 & 290 & 70 & 7 & 6.3 \\
\hline 7 & 150 & 130 & 10 & 9 \\
\hline 8 & 170 & 70 & 7 & 6.3 \\
\hline 9 & 190 & 90 & 8 & 7.2 \\
\hline 10 & 600 & 220 & 5 & 4.5 \\
\hline 11 & 290 & 80 & 4 & 3.6 \\
\hline 12 & 230 & 60 & 7 & 6.3 \\
\hline 13 & 460 & 280 & 14 & 12.6 \\
\hline 14 & 470 & 270 & 8 & 7.2 \\
\hline 15 & 340 & 170 & 19 & 17.1 \\
\hline 16 & 1570 & 440 & 13 & 11.7 \\
\hline 17 & 480 & 130 & 12 & 10.8 \\
\hline 18 & 710 & 250 & 8 & 7.2 \\
\hline 19 & 230 & 140 & 10 & 9 \\
\hline 20 & 170 & 90 & 3 & 2.7 \\
\hline 21 & 350 & 100 & 6 & 5.4 \\
\hline 22 & 230 & 180 & 8 & 7.2 \\
\hline 23 & 200 & 190 & 5 & 4.5 \\
\hline 24 & 210 & 50 & 3 & 2.7 \\
\hline 25 & 180 & 110 & 8 & 7.2 \\
\hline 26 & 130 & 90 & 6 & 5.4 \\
\hline 27 & 230 & 70 & 2 & 1.8 \\
\hline 28 & 130 & 130 & 6 & 5.4 \\
\hline Average & 352.9 & 147.5 & 7.7 & 6.9 \\
\hline
\end{tabular}

The imaged channel belt cannot be a tunnel valley system formed at the base of an ice stream, nor be a submarine channel system. Tunnel valleys are typically elongated, subglacial channels over several kilometers long, forming canyon morphologies and anastomosing networks that are several hundred meters deep and more than $2 \mathrm{~km}$ wide (Ó Cofaigh, 1996; Huuse and Lykke-Andersen, 2000; Stackebrandt, 2009; Stewart and others, 2013; Hammer and others, 2016; Reinardy and others, 2017). Subglacial meltwater channels in Antarctica are further documented to both deepen and becoming increasingly focused in the downstream segment (Anderson and Fretwell, 2008; Simkins and others, 2017). Subglacial landforms generated by meltwater flows have expressions different from those identified in the Bjørnelva River Valley (Munro-Stasiuk and others, 2009). Whereas submarine channels can erode several tens of meters along the slope (e.g. Smith and others, 2007, Monterey Canyon), submarine braided channels do not have the power to erode up to $23 \mathrm{~m}$ into the bedrock of the shelf. Bjørnelva River Valley is thus a fluvial system with distinctive sedimentary elements preserved on a meter-scale resolution.

The age of the Bjørnelva River Valley is constrained in this study using paleo-geographic reconstructions, ice-sheet reconstructions and climate dynamics. In addition, sediments from wells intersecting the Bjørnøyrenna trough mouth fan include sands of Early Quaternary age (www.npd.no, 2018), indicating that the Barents Sea Ice Sheet may have transited the shelf forming a shelf-crossing trough in that time. Knies and others (2009) suggest that the Barents Sea Ice Sheet developed into a moderate 


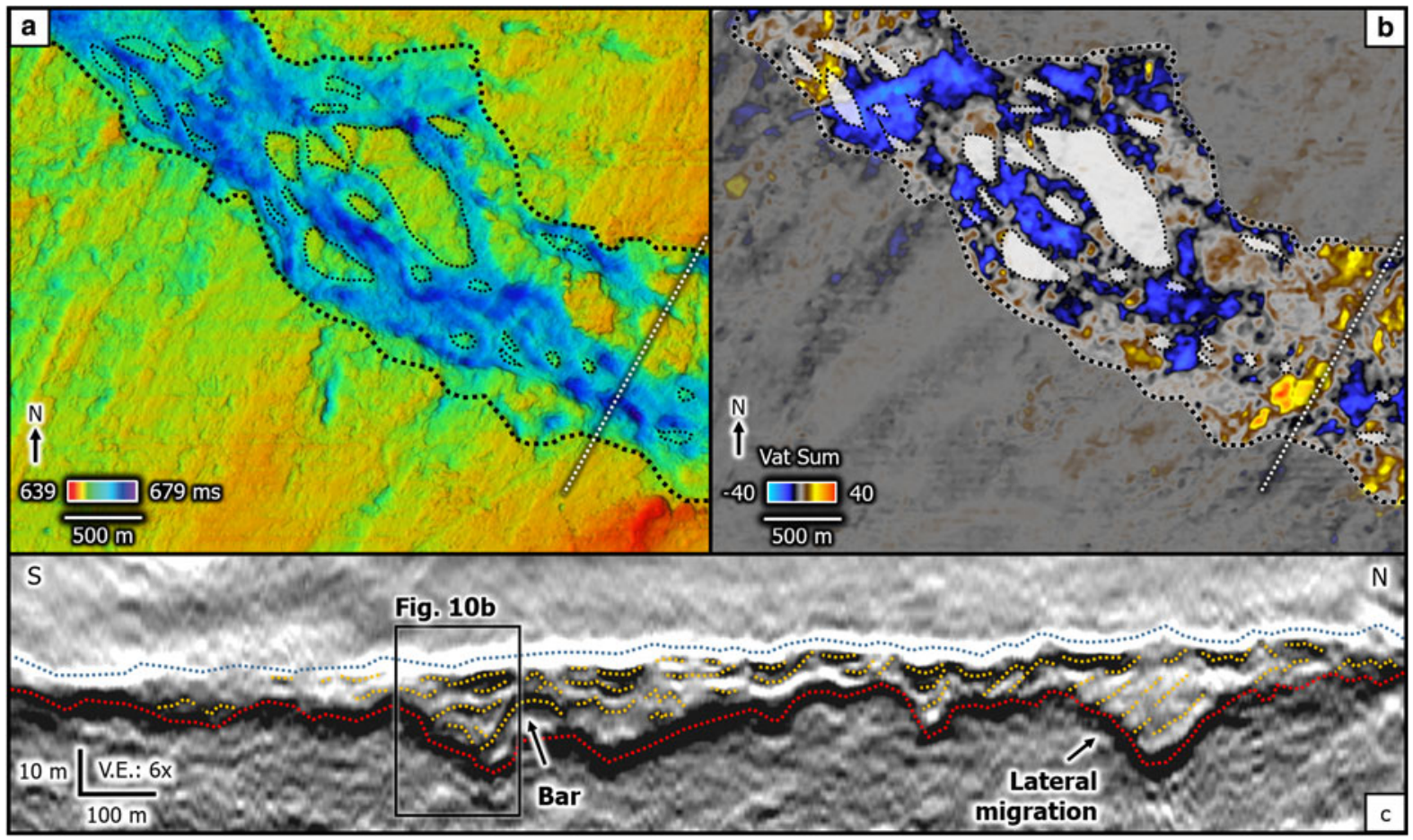

Fig. 9. Seismic characterization of the valley-infill succession between the Top channel reflection and the URU (HR14). (a) Structure map with valley extent and bars is indicated by black stippled lines. (b) Sum of seismic amplitudes of valley infill, showing the deposits to be dominated by negative-amplitude reflections. White polygons outline bars. (c) Seismic profile of the valley-infill succession between the Top channel (blue line) and the URU reflection (red line). The valley infill includes buried bars, horizontally deposited and inclined layers (yellow lines), as well as more chaotic sequences. Location is shown in Figure $2 \mathrm{~b}$.

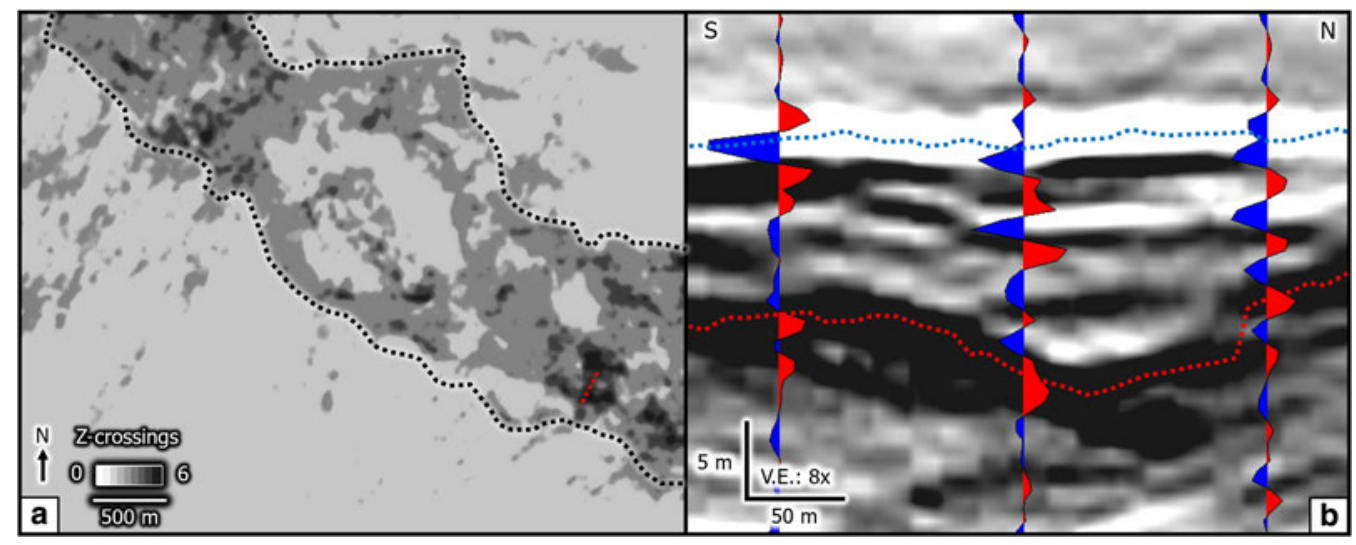

Fig. 10. Reflection characteristics of the valley-infill succession (HR14). (a) Layering characterizing valley infill defined by number of Z-crossings within the valley. (b) Seismic profile showing the layering of valley infill. Three seismic traces show the number of crossings that have been detected in the valley infill of a selected channel. Positive polarity of the signal colored in red, negative polarity colored in blue. Location of seismic profile in (b) is shown as red stippled line in (a).

size in the time period between 2.4 and 1.0 Ma. The Hoop area could then have been influenced by a proglacial braided river during one or more of glacial retreats in the Early Quaternary. Subaerially exposed until $\sim 1 \mathrm{Ma}$ (Dimakis and others, 1998; Butt and others, 2002), we suggest the Bjørnelva River Valley to have formed with a retreating Barents Sea Ice Sheet during a glacial-interglacial cycle between 2.4 and 1.0 Ma.

\subsection{A large glacial lake outburst flood}

After having shown the fluvial origin of Bjørnelva River Valley, we here discuss the glacial and hydrological configuration prevailing for its formation. An active Barents Sea Ice Sheet at the time of the Bjørnelva River Valley formation, with a margin in the central or Southern Barents Sea, is required to feed the braided channel system with meltwater (Figs 12b, 13a). At that time, the ice sheet was retreating and leaving a proglacial river to occupy the former glaciated shelf. This stage of Bjørnelva River Valley, however, predates the valley identified in the 3-D seismic data. This ice-sheet configuration with ice in the Southern Barents Sea, however, does not represent a major ice-streaming phase (Knies and others, 2009; Patton and others, 2016; Fig. 1a). Glacio-fluvial erosion controlled by episodic catastrophic flood events sourced from a retreating Barents Sea Ice Sheet (Fig. 13b) is the most likely process to truncate the URU in this area of the Barents Sea. Therefore, the deep Bjørnelva River Valley could have been created following the same high-energy processes involved in the formation of the valleys in the English Channel (Gupta and others, 2007; Collier and others, 2015), the Münsterland Embayment (Meinsen and others, 2011), or the Coronation - Spondin Scabland in the Canadian Prairies (Sjogren and Rains, 1995). The Bjørnelva River Valley could have been formed by multiple 


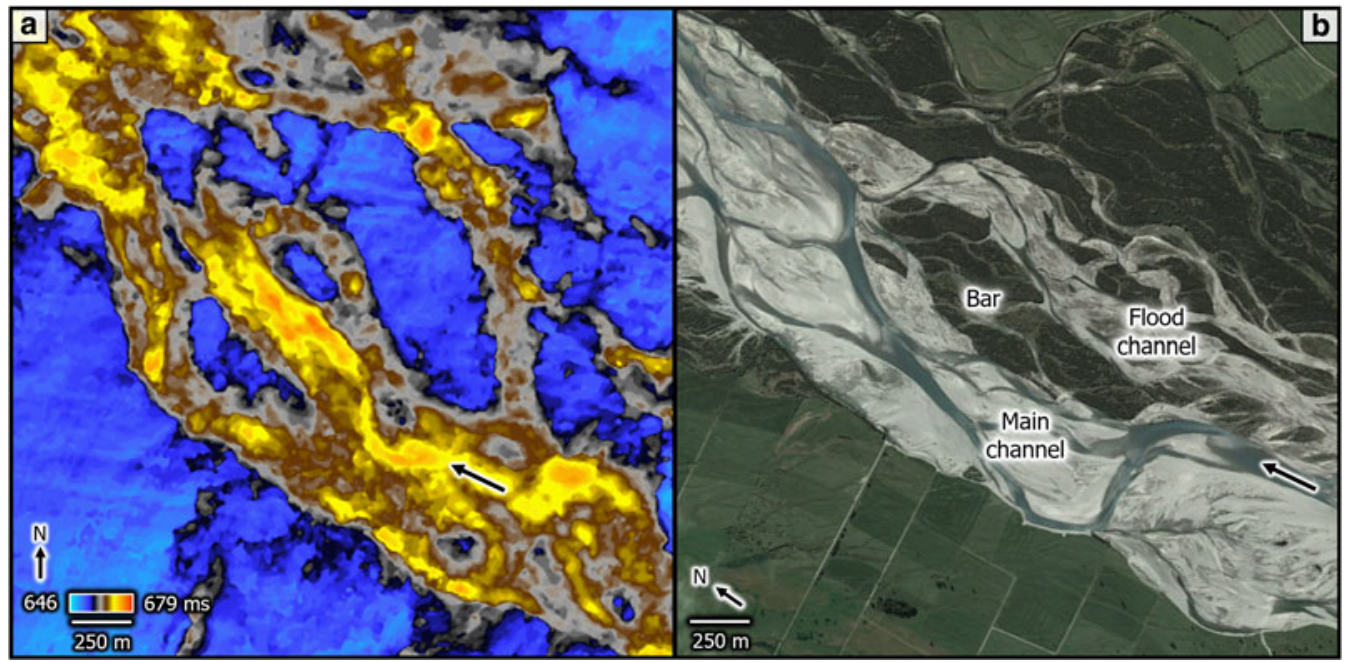

Fig. 11. Comparison of modern braided river with Bjørnelva River Valley. (a) Meter-scale glaciofluvial morphologies of Bjørnelva River Valley are identified in HR14. (b) Braided river system of Whataroa River, South New Zealand. Image from GoogleEarth, produced by Landsat/Copernicus on 6 April 2011. The figures are identical in horizontal scale. Arrows indicate flow direction.

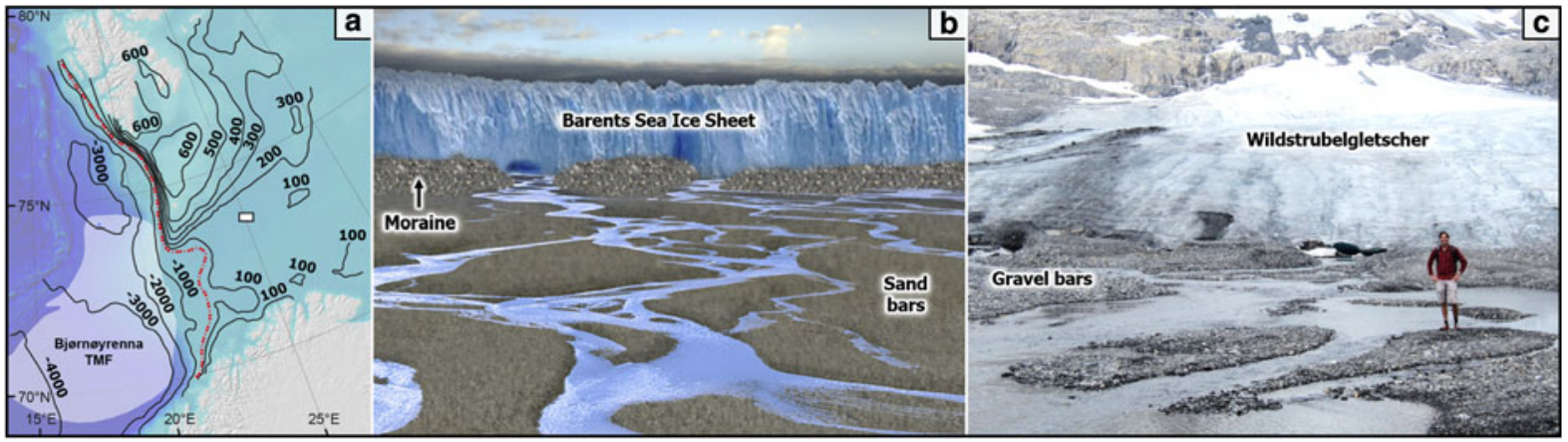

Fig. 12. Braided rivers in proglacial environments. (a) Paleo-geographic reconstruction of the western Barents Sea for the mid-Pliocene, showing that the western Barents Sea was subaerially exposed (modified after Dimakis and others (1998)). Positive numbers indicate meters above sea level and negative numbers indicate meters below sea level. Study area is shown as white box. (b) Conceptual sketch for the formation of Bjørnelva River in the Early Pleistocene, showing the retreat from a moderate-size Barents Sea Ice Sheet. Figure credit: Peter Sanderson. (c) Analogue of an evolving braided river related to glacier melting in the Swiss Alps (Wildstrubelgletscher, Valais). The channel bars are more coarse-grained here. Photo by Bruno Bellwald.

separate Jøkulhlaups with wide ranges of magnitudes, as also suggested for megafloods in North America and Greenland (Baker and Bunker, 1985; Keisling and others, 2020; O'Connor and others, 2020). Glacier-outburst generated floods can last minutes to years (e.g. O'Connor and Baker, 1992; Roberts, 2005; Wingham and others, 2006; Howat and others, 2015; Fricker and others, 2016). The discrepancy between the depth and width of the incised Bjørnelva River with modern braided river datasets (Figs $8 \mathrm{~d}-\mathrm{f}$ ) supports such a catastrophic and high-energy regime for the valley formation. Compared to the geometries of modern rivers, abrasion by bedload from a regular proglacial streamflow is a rather unlikely mechanism for eroding several tens of meters into URU. As the structure map is an amalgamated surface, the braided bars might represent landforms related to repeated fluvial intervals.

We suggest the deepest channels of Bjørnelva River Valley to be potentially formed by repeated outburst floods (Fig. 13b). These outbursts have eroded earlier phases of deposition (Fig. 13a). As the outburst stopped and the discharge dropped, the braided bars formed by a hydrodynamic regime are comparable to modern braided rivers (Figs 12, 13c). The water discharge along the valley is thus characterized by rapid and frequent variations. Catastrophic floods in subaerial braided channels can produce extreme channel and braided bars re-organization when compared to more quiet periods (Fig. 13c), similarly to the Squamish River flood in 1984 (Hickin and Sichingabula, 1988).

The fresh water outbursts associated with the Bjørnelva River Valley formation would have a peak discharge of more than $160000 \mathrm{~m}^{3} \mathrm{~s}^{-1}$, assuming that the discharge during the outburst filled the valley. The morphological configuration for this type of outburst could have prevailed during the Early Pleistocene, when the Barents Sea was a subaerial platform and the Barents Sea Ice Sheet expanded towards the Southern Barents Sea (Butt and others, 2002; Knies and others, 2009). At that time, Dimakis and others (1998) modelled an altitude of $\sim 100 \mathrm{~m}$ a.s.l. for the study area. A formation of a river after $1 \mathrm{Ma}$ is rather unlikely, as the study area was submerged and affected by large glaciations. Based on the age constrains of these events, we suggest Bjørnelva River Valley to have formed in the Early Pleistocene. Isolated from terrestrial exposure, the subsequent drowning of the region could have contributed to the preservation of the paleo-landscape.

The volumes of water are comparable to outburst floods from massive subglacial or ice-marginal lakes (e.g. Lewis and others, 2006; Murton and others, 2010; Høgaas and Longva, 2016; Hjelstuen and others, 2018) (Table 2). The nature of the water storage for the Bjørnelva River Valley, either by rupture of an ice dam or a drainage of a subglacial lake, is unknown at this 


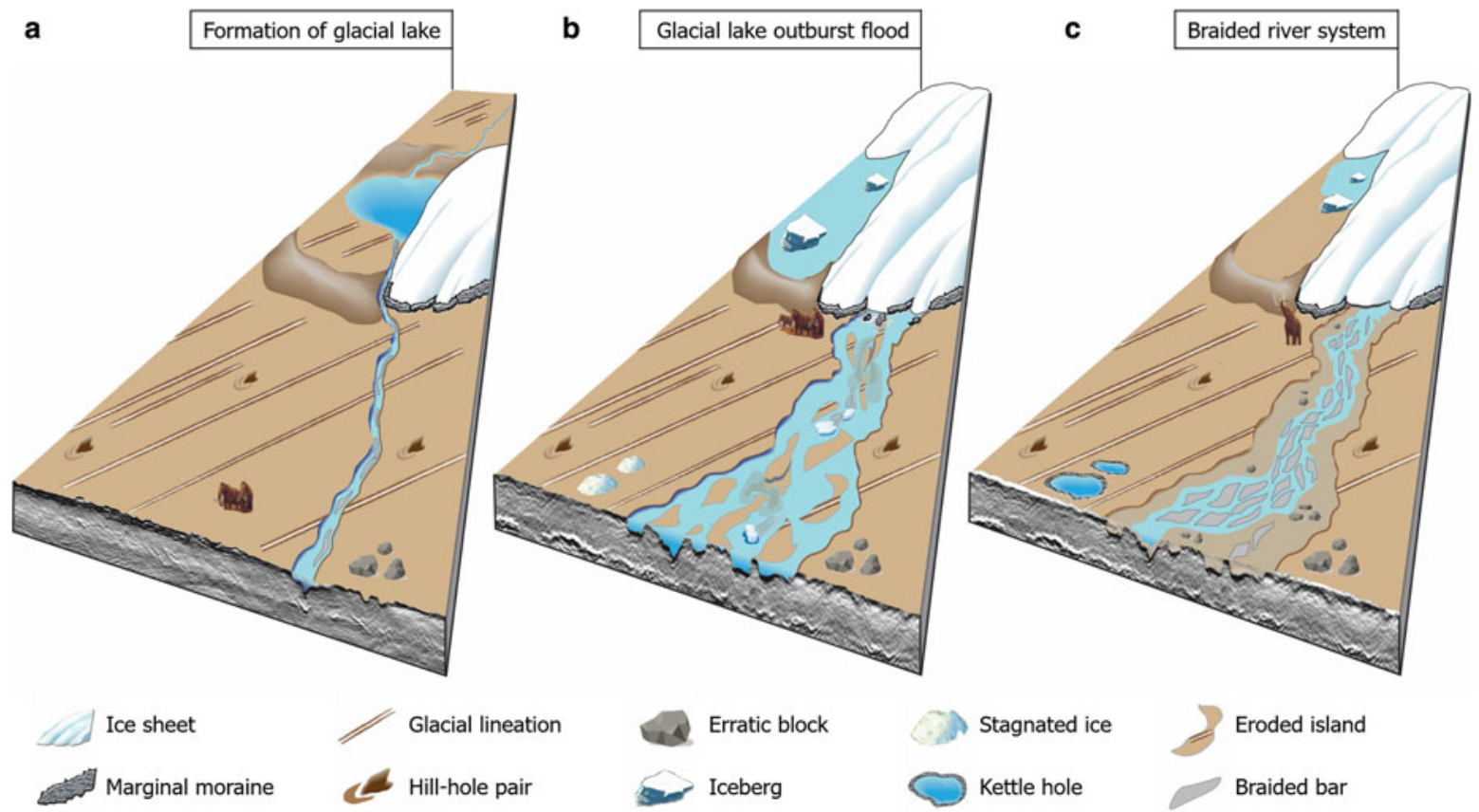

Fig. 13. Conceptual model for the formation of the Bjørnelva River Valley during the Early Pleistocene. (a) Retreating Barents Sea Ice Sheet leaves a proglacial river to occupy the formerly glaciated shelf and forms an ice-marginal glacial lake. Mega-scale glacial lineations along URU indicate that ice had previously advanced over the region. (b) Glacial lake outburst flood. Glacial lake is dammed by the Barents Sea Ice Sheet and drains subglacially or ice-marginally during a catastrophic event. Bjørnelva River cuts several meters into Cretaceous sedimentary bedrock and forms an incised valley. (c) Braided river system with drained lake and decreased discharge compared to outburst. Braided bars form in a riverbed shaped by the glacial lake outburst.

Table 2. Select glacial lake outburst floods

\begin{tabular}{|c|c|c|c|c|}
\hline Flood event & Failure & $\begin{array}{l}\text { Peak discharge } \\
\mathrm{m}^{3} \mathrm{~s}^{-1}\end{array}$ & Age & Reference \\
\hline Vatnajökull Iceland & Subglacial lake & 50000 & 1996 & Snorrason and others (2002), Russell and others (2007) \\
\hline Russell Fiord Alaska & Ice-dammed lake & 105000 & 1986 & Mayo (1988) \\
\hline Lake Agassiz Central North America & Ice-dammed lake & 5000000 & $8 \mathrm{ka} \mathrm{BP}$ & $\begin{array}{l}\text { Smith and Fisher (1993), Teller and others (2002), } \\
\text { Clarke and others (2004) }\end{array}$ \\
\hline Lake Nedre Glomsjø SE Norway & Ice-dammed lake & 170000 & 10 ka BP & Høgaas and Longva (2016), Berthling and Sollid (1999) \\
\hline Bonneville Floods Utah, NW United States & Ice-dammed lake & 1000000 & $18 \mathrm{ka} \mathrm{BP}$ & O'Connor and others $(2020)$ \\
\hline Missoula Floods Montana, NW United States & Ice-dammed lake & $>6500000$ & 19-13 ka BP & $\begin{array}{l}\text { O'Connor and others (2020), Denlinger and O'Connell (2010), } \\
\text { Benito and O'Connor (2003), O'Connor and Baker (1992) }\end{array}$ \\
\hline North Sea Lake North Sea & Ice-dammed lake & $>100000$ & 19 ka BP & Hjelstuen and others (2018) \\
\hline Glacial Lake Weser Münsterland Embayment & Ice-dammed lake & $>250000$ & 130-300 ka BP & Meinsen and others (2011) \\
\hline Strait of Dover North Sea & Ice-dammed lake & 1000000 & 200 ka BP & Gupta and others (2007) \\
\hline Kuray Altai, Russia & Ice-dammed lake & 18000000 & Late Pleistocene & Baker and others (1993) \\
\hline Labyrinth Western Dry Valleys, Antarctica & Subglacial lake & 2000000 & Miocene & Lewis and others (2006) \\
\hline Bjørnelva River Barents Sea & Unknown & $>160000$ & Early Pleistocene & This study \\
\hline
\end{tabular}

time. Topographic highs at the URU to the southeast of the study area (Fig. 2b) could have acted as obstacles for subglacial drainage. Large volumes of water could also be dammed by ice to form a large lake at a location yet to be identified. The development of large potential subglacial lakes has been suggested for locations close to the Norwegian coast, with drainage networks towards Bjørnøyrenna (Shackleton and others, 2018). Thus, we suggest that the Bjørnelva River Valley was originally carved by catastrophic outbursts of an ice-dammed lake in the proglacial domain of the Barents Sea Ice Sheet (Fig. 13b) or a subglacial lake of large volume and eroded Lower Cretaceous bedrock over a distance of $>25 \mathrm{~km}$. The flow velocities of characteristic glacial lake outburst floods are suggested between 5 and $15 \mathrm{~m} \mathrm{~s}^{-1}$ (Baker, 2002) and our estimated average velocity of $6 \mathrm{~m} \mathrm{~s}^{-1}$ for Bjørnelva River fits this range. This study thus shows that two different hydrological regimes are preserved in the seismic data: an outburst regime carving the deepest channels and a less-energetic proglacial braided river regime forming the river bars. We show that these catastrophic high-energy floods can carve several tens of meters over widths of $>1 \mathrm{~km}$ and distances of $>25 \mathrm{~km}$.

\subsection{Paleo-geographic reconstructions}

The paleo-slope gradient of ancient river systems is a fundamental parameter required to reconstruct paleo-hydrology and paleoclimate from the fluvial sedimentary record (Castelltort, 2018). Previous studies document a correlation between the slope gradient of modern braided rivers and the median grain size of the channel infill (Fig. 8c) (Schumm, 1985). An implied paleo-river gradient of $0.64 \pm 0.1 \mathrm{~m} \mathrm{~km}^{-1}$ by the global database (Fig. $8 \mathrm{~b}$ ) is in the same order of magnitude as a measured slope angle of $\sim 2.5 \mathrm{~m} \mathrm{~km}^{-1}$ in the structure maps (Fig. $2 \mathrm{~b}$ ). The fact that the surface gradient in the seismic data $\left(2.5 \mathrm{~m} \mathrm{~km}^{-1}\right)$ is higher than the reconstructed paleo-slope gradient $\left(0.64 \mathrm{~m} \mathrm{~km}^{-1}\right)$ could also be explained by a slightly increased erosion rate in the deeper Bjørnøyrenna in the northwest of the channel system. This 
increased erosion rate is supported by the observation of several ice-streaming events in that area (Piasecka and others, 2016), which occurred after the formation of the incised valley. Even if the isostatic response due to glacial load does not significantly vary in this part of the former Barents Sea Ice Sheet (Fjeldskaar and Amantov, 2018), glacio-isostatic adjustment could also explain the differences in the gradients. Further comparisons with the river database of Church and Rood (1983) show that the Bjørnelva River Valley characteristics are consistent with a gently dipping, wide and deep channel system (Figs 8d-f).

Proglacial landscapes are dynamic environments with diurnal and seasonal fluctuations in discharge as well as glacial-interglacial fluctuations in ice position and amounts of precipitation and meltwater (Russell and others, 1995; Stott, 2002; Roberts, 2005; Lewis and Smith, 2009; Rennermalm and others, 2012). Channels and braided bars are usually highly mobile, with the layout often changing significantly during flood events (Ashmore, 1991; Ferguson, 1993; Knighton, 1998; Church, 2006). The landforms observed in the seismic data here might therefore be a snapshot of the last major reorganization of the Bjørnelva River Valley region (Fig. 13). The preservation of the river system further implies that the subsequent Quaternary glaciations did not completely erase the pre-existing geomorphology, but that ancient surfaces can still retain their original landforms. Similar to the Barents Sea, glacial erosion has preserved pre-existing fluvial landscapes in the Convoy Range to Mackay Glacier area in Antarctica (Lowe and Anderson, 2003; Sugden and Denton, 2004; Denton and Sugden, 2005; Lewis and others, 2006) and the Petermann Canyon in Greenland (Bamber and others, 2013; Cooper and others, 2016; Keisling and others, 2020). The preservation of paleo-landscapes, even though subsequently glaciated, implies that the shallow subsurface of the SW Barents Sea can be used to reconstruct geological processes of the Neogene and Quaternary time periods.

\subsection{Channel infill}

Here we discuss the significance of the sedimentary deposits characterizing the valley infill. Subglacial erosion, glacial reworking and glaciofluvial erosion are common processes shaping glacier forefields in modern braided rivers (Fig. 12b, c) (e.g. Willis and others, 1996). River bars consist of coarser-grained material, such as sand and gravel (Fig. 12b) (Buffington and Montgomery, 2013). As the strata underlying the URU consist of Lower Cretaceous sandstone (small share), limestone and marl (www.npd.no, 2018), the bars in the study area likely represent reworked Cretaceous bedrock material. With a slope of $0.64 \mathrm{~m} \mathrm{~km}^{-1}$, the median grain size of comparable modern braided rivers falls into a first cluster from $\sim 0.1$ to $1 \mathrm{~mm}$ (i.e. sand) and a second cluster from 10 to $100 \mathrm{~mm}$ (i.e. gravel and pebbles, Fig. 8c). However, the Kernel density plot favors a sandy valley infill (Fig. 8c). As the infill of Bjørnelva River Valley is most likely dominated by the glacio-erosive products related to a large ice sheet, we suggest the deposits to consist mostly of sands rather than gravels. The horizontal to slightly dipping reflections within the individual channels of Bjørnelva River Valley could represent coarse-grained glaciofluvial sands, typically downlapping and onlapping the erosional channel surface (Figs $3 c, 9 c)$. This interpretation is supported by channel infill reported to consist of glaciofluvial gravelly sand intercalated with till in the SW Barents Sea (Sættem and others, 1992).

Marine shales dominate the Lower Cretaceous sequence subcropping the URU in large parts of the SW Barents Sea (www.npd.no, 2018). Sandstones are more typical for Middle-Lower Jurassic and Upper Triassic strata, which are subcropping in large areas to the north of the study area and on the Loppa and Fedynsky highs (Fig. 1). Because of its origin to the south, we suggest that Bjørnelva River could transport sandy sediments eroded in the nearby Loppa High (Fig. 1a).

The acoustically chaotic basal part of the channel infill (Fig. 4b) most likely consists of coarser-grained gas-charged fluvial sands, thus explaining the negative-amplitude seismic reflections (Fig. 9b). On the other hand, the horizontally layered sediments in the upper part of the succession in the valley infill represent fine-grained fluvial deposits (Fig. 10). The different facies of the valley infill may represent distinct phases of the channel belt formation. Coarser-grained chaotic deposits at the base might be linked to the high-energy glacial lake outbursts (Fig. 13b), whereas overlying layered sediments could have a more turbiditic origin, reflecting fine-grained sediments deposited during low-energy braided river conditions or the waning of floods (Fig. 13c) (e.g. Meinsen and others, 2011). The possibility of coarser-grained sediments deposited during more high-energic hydrological regimes is supported by grain-size analysis of proglacial rivers in Greenland (Hasholt and others, 2013). These studies show that the transported sediments mainly consist of grain sizes finer than sand, except during high-flow events (Hasholt and others, 2013). The high-amplitude Top channel reflection could represent sediments related to flood events spreading over larger URU regions and hence correspond to deposits similar to commonly documented flood plains. The chaotic reflections preserved in the sediment stratigraphy of the Bjørnelva River Valley infill support the existence of high-energy floods. The valley infill is furthermore valuable for identifying potential sources of the interpreted sands.

\subsection{Pleistocene and historic analogues}

We have concluded Bjørnelva River Valley to be formed by a catastrophic glacial lake outburst along a previously glaciated shelf and here we investigate how this event compares with both historic and pre-historic glacial floods. Values for the peak discharge of well-established Pleistocene megaflood terrains range between 0.6 and $18 \times 10^{6} \mathrm{~m}^{3} \mathrm{~s}^{-1}$ (Collier and others, 2015). Defined by the hydraulic radius and the valley slope, the calculated discharge of $160000 \mathrm{~m}^{3} \mathrm{~s}^{-1}$ for the Bjørnelva River outburst is comparable to the discharge of the largest modern rivers (e.g. Amazon: $170000 \mathrm{~m}^{3} \mathrm{~s}^{-1}$; Prestes and others, 2020). However, such quantities of water might only have been flowing through the valley during extreme and short events, corresponding to glacial lake outburst floods triggered by dam failure (Fig. 13b) (Smith and Fisher, 1993; Gupta and others, 2007; Wiedmer and others, 2010; Denlinger and O'Connell, 2010). The Missoula Floods in Montana and the Late Pleistocene superfloods in the Altai mountains are the largest prehistoric glacial lake outburst floods (Baker and others, 1993; Benito and O'Connor, 2003; Rudoy, 2012), whereas the Skeidara River Flood caused by an outburst from Vatnajökull in 1996 is a more recent example (Snorrason and others, 2002; Russell and others, 2007) (Table 2).

An estimated discharge of $160000 \mathrm{~m}^{3} \mathrm{~s}^{-1}$ is comparable to modern glacial outburst floods, such as Russell Fiord in Alaska, the Vatnajökull ice cap in Iceland or the Pleistocene ice-dammed lakes in the North Sea (Mayo, 1988; Russell and others, 2007; Meinsen and others, 2011; Hjelstuen and others, 2018) (Table 2). The floods of Lake Nedre Glomsjø in SE Norway, with a peak discharge of $170000 \mathrm{~m}^{3} \mathrm{~s}^{-1}$ and a flood height of 80-90 $\mathrm{m}$, eroded the huge Jutulhogget canyon and are the best studied outburst floods from the Norwegian mainland (Berthling and Sollid, 1999; Høgaas and Longva, 2016). The Glacial Lake Weser outburst flood $\left(>250000 \mathrm{~m}^{3} \mathrm{~s}^{-1}\right)$ eroded up to $30 \mathrm{~m}$ into Cretaceous basement (limestone and marlstone) and created up to $4 \mathrm{~km}$-wide channels in front of overspill 
channels (Meinsen and others, 2011) and is suggested to be a good analogue to the erosive character related to the formation of the Bjørnelva River Valley. Erosion of weak, late Cretaceous bedrock and preexisting glaciogenic sediments in short-duration sheetfloods was also the dominating geological process shaping the Coronation - Spondin Scabland in the Canadian Prairies (Sjogren and Rains, 1995).

The Petermann Canyon, an up to $800 \mathrm{~m}$ deep megacanyon in Greenland is suggested to have been shaped by repeated megafloods in the Pliocene-Pleistocene (Keisling and others, 2020). The canyon morphology could have formed by running water prior to extensive glaciation (Bamber and others, 2013; Cooper and others, 2016). With a vertical erosion of $1-20 \mathrm{~m}$ per flood event, the suggested mechanism required 40-800 jøkulhlaup-like floods (Keisling and others, 2020). Both maximum erosion of $20 \mathrm{~m}$ per flood event and a proglacial environment prior to the extensive glaciation highlights the potential analogy between Petermann Canyon in Greenland and Bjørnelva River Valley in the Barents Sea.

Flow-erosive events have implications for modern settlements downstream glaciated catchment areas, as ice melting related to ongoing climate change and the development of ice-marginal and subglacial lakes may evolve into severe geohazards (Roberts, 2005; Huss and others, 2007; Baker, 2008; Bajracharya and Mool, 2009; Dussaillant and others, 2010; Carrivick and Tweed, 2016; Harrison and others, 2018; Shugar and others, 2020). This study shows that the Bjørnelva River outburst floods cut more than 20 $\mathrm{m}$ into sedimentary bedrock over distances of several tens of kilometers. Landforms and landscapes related to catastrophic megafloods have been revealed in increasing detail from Mars (e.g. Robinson and Tanaka, 1990), where the discharges formed by lake spillways have been calculated from 5 to $20 \times 10^{6} \mathrm{~m}^{3} \mathrm{~s}^{-1}$ (Komar, 1979; Irwin and others, 2004). Distinctive fluvial signatures from Earth are valuable for interpretations of landforms and sedimentary records on planets with limited subsurface information. Thus, the hydrologic and erosive character of the Bjørnelva River outburst have large-scale implications not only for Earth, but also for other terrestrial planets (e.g. Mars).

\subsection{Comparison of erosive and depositional patterns}

Cataclysmic glacial outburst floods erode large channels and canyon networks (Smith, 1993; Larsen and Lamb, 2016), and abrupt cessation of these flows can leave coarse deposits (Baker, 1973; Sjogren and Rains, 1995; O'Connor and others, 2020). The landscape of the Coronation - Spondin Scabland in the Canadian Prairies formed in front of the retreating Laurentide Ice Sheet and outburst floods left discontinuous gravel beds, large boulders and bedrock clasts (Sjogren and Rains, 1995). Such erosional products have not been deposited by the Bjørnelva River outburst flood, as these large deposits would be detectable in highresolution 3-D seismic (Lebedeva-Ivanova and others, 2018). This difference in depositional patterns can be explained by a catchment dominated by sedimentary bedrock for the region of the Bjørnelva River Canyon (Fig. 1).

While the deposits from the Bjørnelva River outburst flood differ from the largest identified events on Earth, the erosional power of the Bjørnelva River is comparable to other paleofloods (Sjogren and Rains, 1995; Meinsen and others, 2011; O'Connor and others, 2020).

Outburst-related landforms expressed at the Earth surface can be studied at larger extents and in higher detail compared to buried paleo-landscapes (Smith, 1993; Høgaas and Longva, 2016; O'Connor and others, 2020). While sedimentological analysis is a common procedure for glaciofluvial erosional morphology and sediments expressed at the Earth surface (Smith, 1993;
O'Connor and others, 2020), boreholes and wells to analyze the canyon infill of this study have yet to be collected.

\subsection{What can we learn from Bjørnelva River for modern rivers?}

The case of the Bjørnelva River outburst flood indicates a discharge of $160000 \mathrm{~m}^{3} \mathrm{~s}^{-1}$ of fresh water on a relatively flat and extensive shelf in the SW Barents Sea during an abrupt hydrologic event, most likely sourced from an ice-dammed or subglacial lake during the Early Pleistocene. In the following, we discuss the implications of this study towards constraining the evolution of glaciated and deglaciated landscapes and mechanistic traits of glacial lake outburst floods.

The incised valley of the Bjørnelva River was shaped by a highenergetic hydrological regime during a Pleistocene deglaciation. The ice-free topographic maps of Greenland and Antarctica show several wide plains where rivers can evolve and relief where lakes may form in the future (Fretwell and others, 2013; Morlighem and others, 2017). Extreme hydrologic events can be significant for the evolution of landscapes in regions currently covered by the Greenland and Antarctic ice sheets. The results of this contribution can be used as a potential analogue to study the morphological evolution of the current landforms developed by the melting of the large ice sheets and leading to outburst processes.

The Antarctic ice sheet is dominated by marine-terminating glacier outlets (Dowdeswell and others, 2016). Numerous paleosubglacial channels incised into crystalline bedrock are exposed on the seafloor of the Antarctic continental shelf and indicate channelized subglacial meltwater drainage fed by upstream subglacial lakes (Lowe and Anderson, 2003; Livingstone and others, 2013; Simkins and others, 2017; Munoz and Wellner, 2018). Radar and altimetric data are common technologies used to detect subglacial lakes across Antarctica and the fourth inventory of Antarctic subglacial lakes includes 379 active subglacial lakes (Wright and Siegert, 2012; Siegfried and Fricker, 2018; MacKie and others, 2020). Dowdeswell and Siegert (1999) estimated a volume of $4000-12000 \mathrm{~km}^{3}$ of water held in 77 of these Antarctic subglacial lakes. The meltwater stored in these lakes can drain over periods of months to several years with potential for reactivation of the channel network (Wingham and others, 2006; Howat and others, 2015; Fricker and others, 2016).

Several discharge events in the order of $10^{2}$ to $10^{3} \mathrm{~m}^{3} \mathrm{~s}^{-1}$ have been reported from Antarctica occurring during the last decades (Siegfried and Fricker, 2018). However, considering landform assemblages and volume estimates, the Labyrinth in the McMurdo Dry Valleys in East Antarctica is a better analogue for the Bjørnelva River Valley formation (Lowe and Anderson, 2003; Sugden and Denton, 2004; Denton and Sugden, 2005; Lewis and others, 2006). The channels forming the Labyrinth incised a sill and shaped a valley up to $600 \mathrm{~m}$ in width and up to $250 \mathrm{~m}$ in depth (Lewis and others, 2006). The maximum estimated discharge for this catastrophic drainage, proposed to have occurred sometime between 14.4 and $12.4 \mathrm{Ma}$, is in the order of $1.6-2.2 \times 10^{6} \mathrm{~m}^{3} \mathrm{~s}^{-1}$ (Lewis and others, 2006). Glacial lakes are rapidly growing in response to climate change and glacier retreat, and the peak in future glacier lake outburst events will most likely lag by several decades the responses of glacier lake systems to current warming (Harrison and others, 2018; Shugar and others, 2020). Large-volume outbursts, such as Bjørnelva River, might thus be more frequent processes on Earth during the next decades and into the 22nd century.

The Greenland ice sheet, on the other hand, comprises both marine- and land-terminating outlets (Dowdeswell and others, 2016). The proglacial hydrologic environment of Greenland consists of rivers and lakes draining the ice margin (Chu, 2014), with 
a total of 434 proglacial meltwater outlets from land-terminating portions of the ice sheet (Lewis and Smith, 2009). Seasonal fluctuations measured in proglacial streams and lakes draining this ice sheet show large uncertainties in discharge (Stott and Grove, 2001; Rennermalm and others, 2012).

Ongoing deglaciation of both the Greenland and Antarctic ice sheet likely exposes terrestrial landscapes, resulting in changes of patterns in glacial meltwater discharge, including the development of proglacial landscapes in Antarctica. The geological archives of Greenland record several historic and Holocene outburst events (Russell and others, 1995; Stott, 2002; Lewis and Smith, 2009; Bamber and others, 2013; Chu, 2014; Cooper and others, 2016; Keisling and others, 2020). Meltwater outburst from large upstream lakes could reshape the highly dynamic proglacial environments and form similar landscapes as the ones proposed for the early Pleistocene in the SW Barents Sea. Our study thus contributes to the knowledge to estimate the range and character (river morphology and sedimentology) of large outburst floods along the margins of these large ice sheets. Large outburst floods might especially affect SW Greenland, where the average annual volumetric meltwater production is highest and hydrologic activity consequently greater compared to East Greenland (Lewis and Smith, 2009).

This study shows that buried wide plains with sharp channels and depositional bars can be preserved in high-resolution, as also observed in deeper stratigraphic levels of the SW Barents Sea (Corseri and others, 2018; Klausen and others, 2019). Wide plains are characteristic landscapes in Arctic regions and the dry and cold climate prevailing in these regions favors the build-up of permafrost (Kanevskiy and others, 2011; Schirrmeister and others, 2013). The Barents Sea at the time of the Bjørnelva River Valley formation is most likely characterized by such a climate and permafrost in the shale-dominated subsurface is discussed for landscape evolution of this paleo-surface (Bellwald and others, 2019). Our study shows that highly erosive fluvial events can occur in such dry and cold climates, a type of event also documented for the Coronation - Spondin Scabland of the Canadian Prairies (Sjogren and Rains, 1995). Decadal outburst events in otherwise calm hydrological conditions, potentially combined with underlying permafrost, might shape upcoming wide plains in Arctic regions (e.g. West Greenland).

Extreme glacial floods further impact infrastructure and society (Roberts, 2005; Huss and others, 2007; Bajracharya and Mool, 2009; Dussaillant and others, 2010; Carrivick and Tweed, 2016; Harrison and others, 2018; Shugar and others, 2020). The geomorphological analysis of Bjørnelva River Valley shows that the channel is deepest closer to the source and shallows with distance. Most pronounced carving closer to the outburst source suggests that the erosive power and consequently destructive potential, for outburst floods on wide plains changes with distance. Diminishing carving downflow of Bjørnelva River Valley most likely implies that the flood discharge was not completely channelized anymore, but rather spilled over a larger area. Bjørnelva River Valley thus highlights that quantitative analyses of paleo-landscapes shaped by outburst flood events can inform geohazard assessments in areas at risk of outburst flooding today. New infrastructure in sensitive areas should be erected in safe zones with respect to the distance of outburst source, considering that the inevitable outburst could be more erosive closer to the source and flood extended areas farther downstream.

\section{Conclusions}

The high-resolution 3-D seismic data from the Hoop area in the SW Barents Sea show that channelized braided meltwater outflow and river bars related to the formation of Bjørnelva River Valley are developed on a glacial paleo-surface (Upper Regional Unconformity, URU). Bjørnelva River carved up to $23 \mathrm{~m}$-deep channels into the Cretaceous sedimentary bedrock formed an average $1500 \mathrm{~m}$-wide fluvial system during the Early Pleistocene. We infer this erosion was caused by one or more successive floods triggered from the outbursts of a lake dammed by the Barents Sea Ice Sheet, resulting in peak water discharges of $\sim 160000 \mathrm{~m}^{3} \mathrm{~s}^{-1}$, a volume comparable to the largest modern glacial lake outbursts.

This study shows that high-energy hydrological events can leave distinctive signatures in the sedimentary records of braided river systems, with two prevailing fluvial regimes in this case: (i) violent glacial lake outbursts carving a valley and channel belt and (ii) a less energetic braided river after the lake outbursts forming the streamlined braided bars. An average bar elongation of $2.54 \pm 0.04$ indicates that braiding and river bar formation of Bjørnelva River occurred along a gently dipping paleo-surface of $0.64 \mathrm{~m} \mathrm{~km}^{-1}$. Our observations show that the Bjørnelva River outburst character changes from carving to spillover along its drainage route and the geomorphologies identified in this contribution help to evaluate the destructive potential of outburst floods. We show that the URU does not only reveal expressions related to repeated large-scale glacial oscillations, but also glaciofluvial expressions formed in subaerial proglacial environments.

Bjørnelva River likely had a large impact on the landscape evolution of the SW Barents Sea, and may further have had an influence on the Barents Sea Ice Sheet dynamics. This contribution further illustrates that highly erosive fluvial events can occur in regions dominated by dry and cold climates, and help close knowledge gaps for the large-scale drainage evolution on Arctic plains during deglaciations. Thus, Bjørnelva River Valley could act as a potential analogue for landscapes developing in regions of the melting Greenland and Antarctic ice sheets.

Acknowledgements. We thank TGS, WGP and VBPR for allowing to publish the seismic data. Peter Sanderson is thanked to use his illustration on braided streams. Romain Corseri is acknowledged for valuable discussions and comments. Sverre Planke and Jan Inge Faleide acknowledge the support from the Research Council of Norway through its Centres of Excellence funding scheme, project 223272 (CEED) and project 228107 (ARCEx). Peter Haeussler, Bobby Reece, and Amy East are acknowledged for productive discussions of the manuscript. We thank the two reviewers Sean Gulick and Julia Wellner as well as the scientific editor Matthew Siegfried and associate chief editor Hester Jiskoot for detailed and constructive feedback.

\section{References}

Alho P, Russell AJ, Carrivick JL and Käyhkö J (2005) Reconstruction of the largest Holocene jökulhlaup within Jökulsa a Fjöllum, NE Iceland. Quaternary Science Reviews 24, 2319-2334.

Anderson JB and Fretwell LO (2008) Geomorphology of the onset area of a paleo-ice stream, Marguerite Bay, Antarctic Peninsula. Earth Surface Processes and Landforms: The Journal of the British Geomorphological Research Group 33(4), 503-512.

Andreassen K and Winsborrow MCM (2009) Signature of ice streaming in Bjørnøyrenna, Polar North Atlantic, through the Pleistocene and implications for ice-stream dynamics. Annals of Glaciology 50(52), 17-26.

Ashmore PE (1991) How do gravel-bed rivers braid? Canadian Journal of Earth Sciences 28, 326-341.

Bajracharya SR and Mool P (2009) Glaciers, glacial lakes and glacial lake outburst floods in the Mount Everest region, Nepal. Annals of Glaciology 50, 81-86.

Baker VR (1973) Paleohydrology and sedimentology of Lake Missoula flooding in eastern Washington. Geological Society of America 144.

Baker VR (2002) High-energy megafloods: planetary settings and sedimentary dynamics. In Martini PI and others (eds), Flood and Megaflood Processes and Deposits: Recent and Ancient Examples. Special Publications of the International Association of Sedimentologists, Wiley Online Library, vol. 32, pp, 3-15.

Baker VR (2008) Paleoflood hydrology: Origin, progress, prospects. Geomorphology 101, 1-13. 
Baker VR, Benito G and Rudoy AN (1993) Paleohydrology of late Pleistocene superflooding, Altay Mountains, Siberia. Science 259, 348-350.

Baker VR and Bunker RC (1985) Cataclysmic late Pleistocene flooding from glacial Lake Missoula: a review. Quaternary Science Reviews 4(1), 1-41.

Bamber JL, Siegert MJ, Griggs JA, Marshall SJ and Spada G (2013) Paleofluvial mega-canyon beneath the central Greenland ice sheet. Science 341, 997-999.

Bellwald B and 6 others (2018b) Detailed structure of buried glacial landforms revealed by high-resolution 3D seismic data in the SW Barents Sea. EAGE Extended Abstracts 2018, 1-5.

Bellwald B and Planke S (2018) Shear margin moraine, mass transport deposits, and soft beds revealed by high-resolution P-Cable 3D seismic data in the Hoop Area, Barents Sea. Special publication. Geological Society of London, Special Publications 477(1), 537-548.

Bellwald B, Planke S, Lebedeva-Ivanova N, Piasecka ED and Andreassen K (2019) High-resolution Landform Assemblage along a Buried Glacio-erosive Surface in the SW Barents Sea Revealed by P-Cable 3D Seismic Data. Geomorphology 332, 33-50.

Bellwald B, Planke S, Piasecka ED, Matar MA and Andreassen K (2018a) Ice-stream dynamics of the SW Barents Sea revealed by high-resolution 3D seismic imaging of glacial deposits in the Hoop area. Marine Geology 402, 165-183.

Benito G and O'Connor JE (2003) Number and size of last-glacial Missoula floods in the Columbia River valley between the Pasco Basin, Washington, and Portland, Oregon. GSA Bulletin 115, 624-638.

Bennett MR, Huddart D and Thomas GSP (2002) Facies architecture within a regional glaciolacustrine basin: Copper River. Alaska. Quaternary Science Reviews 21, 2237-2279.

Berthling I and Sollid JL (1999) The drainage history of glacial lake Nedre Glomsjø, southern Central Norway. Norwegian Journal of Geography 53 (4), 190-201.

Bjarnadóttir LR, Rüther DC, Winsborrow MCM and Andreassen K (2013) Grounding-line dynamics during the last deglaciation of Kveithola, W Barents Sea, as revealed by seabed geomorphology and shallow seismic stratigraphy. Boreas 42, 84-107.

Bjarnadóttir LR, Winsborrow MCM and Andreassen K (2017) Large subglacial meltwater features in the central Barents Sea. Geology 45(2), 159-162.

Booth DB and Hallet B (1993) Channel networks carved by subglacial water: observations and reconstruction in the eastern Puget Lowland of Washington. Geological Society of America Bulletin 105(5), 671-683.

Boyd R, Scott DB and Douma M (1988) Glacial tunnel valleys and Quaternary history of the outer Scotian shelf. Nature 333, 61-64.

Buffington JM and Montgomery DR (2013) Geomorphic classification of rivers. In Shroder JF (ed.), Treatise on Geomorphology. San Diego: Academic Press, pp. 730-767.

Butt FA, Drange H, Elverhøi A, Otterå $\mathbf{O H}$ and Solheim A (2002) Modelling Late Cenozoic isostatic elevation changes in the Barents Sea and their implications for oceanic and climatic regimes: preliminary results. Quaternary Science Reviews 21, 1643-1660.

Carmarck E and 18 others (2015) Toward quantifying the increasing role of the oceanic heat in sea ice loss in the new Arctic. Bulletin of the American Meteorological Society 96(12), 2079-2105.

Carrivick JL and Tweed FS (2013) Proglacial lakes: character, behavior and geological importance. Quaternary Science Reviews 78, 34-52.

Carrivick JL and Tweed FS (2016) A global assessment of the societal impacts of glacier outburst floods. Global Planetary Change 144, 1-16.

Castelltort S (2018) Empirical relationship between river slope and the elongation of bars in braided rivers: a potential tool for paleoslope analysis from subsurface data. Marine and Petroleum Geology 96, 544-550.

Chu VW (2014) Greenland Ice sheet hydrology: a review. Progress in Physical Geography 38(1), 19-54.

Church M (2006) Bed material transport and the morphology of alluvial river channels. Annual Review of Earth and Planetary Sciences 34, 325-354

Church M and Rood K (1983) Catalogue of Alluvial River Channel Regime Data. Vancouver: Department of Geography, University of British Columbia.

Clark PU and 5 others (2001) Freshwater forcing of abrupt climate change during the last glaciation. Science 293, 283-287.

Clarke GK, Leverington DW, Teller JT and Dyke AS (2004) Paleohydraulics of the last outburst flood from glacial Lake Agassiz and the 8200 BP cold event. Quaternary Science Reviews 23, 389-407.

Collanega L, Massironi M, Breda A and Kjølhamar BE (2017) Onset of N-Atlantic rifting in the Hoop Fault Complex (SW Barents Sea): an orthorhombic dominated faulting? Tectonophysics 706-707, 59-70.
Collier JS and 5 others (2015) Streamlined islands and the English Channel megaflood hypothesis. Global and Planetary Change 135, 190-206.

Cooper MA, Michaelides K, Siegert MJ and Dyke AS (2016) Paleofluvial landscape inheritance for Jakobshavn Isbræ catchment, Greenland. Geophysical Research Letters 43, 6350-6357.

Corseri R and 6 others (2018) A diverted submarine channel of early cretaceous age revealed by high-resolution seismic data, SW Barents Sea. Marine and Petroleum Geology 98, 477-490.

Darmadi Y, Willis BJ and Dorobek SL (2007) Three-dimensional seismic architecture of fluvial sequences on the low-gradient Sunda Shelf, Offshore Indonesia. Journal of Sedimentary Research 77, 225-238.

Denlinger RP and O'Connell DRH (2010) Simulations of cataclysmic outburst floods from Pleistocene Glacial Lake Missoula. Bulletin 122(5-6), 678-689.

Denton GH and Sugden DE (2005) Meltwater features that suggest Miocene ice-sheet overriding of the transantarctic Mountains in Victoria Land, Antarctica. Geografiska Annaler: Series A, Physical Geography 87(1), 67-85.

Détriché S and 6 others (2010) Caesium-137 in sandy sediments of the river Loire (France): assessment of an alluvial island evolving over the last 50 years. Geomorphology 115, 11-22.

Dimakis P, Braathen BI, Faleide JI, Elverhøi A and Gudlaugsson ST (1998) Cenozoic erosion and the preglacial uplift of the Svalbard-Barents Sea region. Tectonophysics 300, 311-327.

Dowdeswell JA and 5 others (2016) Introduction: an atlas of submarine glacial landforms. Geological Society, London, Memoirs 46(1), 3-14.

Dowdeswell JA and Siegert MJ (1999) The dimensions and topographic setting of Antarctic subglacial lakes and implications for large-scale water storage beneath continental ice sheets. Geological Society of America Bulletin $111(2), 254-263$.

Duller RA and 6 others (2012) Abrupt landscape change post-6 Ma on the central Great Plains, USA. Geology 40, 871-874.

Dussaillant A and 5 others (2010) Repeated glacial-lake outburst floods in Patagonia: an increasing hazard? Natural Hazards 54, 469-481.

Ferguson RI (1993) Understanding braiding processes in gravel-bed rivers: progress and unsolved problems. In Best JL and Bristow CS eds. Braided Rivers. London: Geological Society of London, 73-87.

Fjeldskaar W and Amantov A (2018) Effects of glaciations on sedimentary basins. Journal of Geodynamics 118, 66-81.

Fretwell P and 6 others (2013) Bedmap2: improved ice bed, surface and thickness datasets for Antarctica. The Cryosphere 7, 375-393.

Fricker HA, Siegfried MR, Carter SP and Scambos TA (2016) A decade of progress in observing and modelling Antarctic subglacial water systems. Philosophical Transactions of the Royal Society A: Mathematical, Physical and Engineering Sciences 374(2059), 20140294.

Gupta S, Collier JS, Palmer-Felgate A and Potter G (2007) Catastrophic flooding origin of shelf valley systems in the English Channel. Nature 448 (7151), 342-345.

Hammer $\varnothing$ and 5 others (2016) Agderia - a postglacial lost land in the southern Norwegian Sea. Norwegian Journal of Geology 96, 43-60.

Harrison S and 14 others (2018) Climate change and the global pattern of moraine-dammed glacial lake outburst floods. The Cryosphere 12(4), 1195-1209.

Hasholt B, Bech Mikkelsen A, Holtegaard Nielsen $M$ and Andreas Dahl Larsen M (2013) Observations of runoff and sediment and dissolved loads from the Greenland ice sheet at Kangerlussuaq, West Greenland, 2007 to 2010. Zeitschrift für Geomorphologie, Supplementary Issues 57(2), 3-27.

Henriksen E and 10 others (2011) Uplift and erosion of the greater Barents Sea: impact on prospectivity and petroleum systems. Geological Society, London, Memoirs 35(1), 271-281.

Hickin EJ and Sichingabula HM (1988) The geomorphic impact of the catastrophic October 1984 flood on the planform of Squamish River, southwestern British Columbia. Canadian Journal of Earth Sciences 25, 1078-1087.

Hjelstuen BO, Sejrup HP, Valvik E and Becker LWM (2018) Evidence of an ice-dammed lake outburst in the North Sea during the last deglaciation. Marine Geology 402, 118-130.

Høgaas F and Longva O (2016) Mega deposits and erosive features related to the glacial lake Nedre Glomsjø outburst flood, southeastern Norway. Quaternary Science Reviews 151, 273-291.

Howat IM, Porter C, Noh MJ, Smith BE and Jeong S (2015) Brief communication: sudden drainage of a subglacial lake beneath the Greenland Ice Sheet. The Cryosphere 9(1), 103-108. 
Huss M, Bauder A, Werder M, Funk M and Hock R (2007) Glacier-dammed lake outburst events of Gornersee, Switzerland. Journal of Glaciology $\mathbf{5 3}$ 189-200.

Huuse M and Lykke-Andersen H (2000) Overdeepened quaternary valleys in the eastern Danish North Sea: morphology and origin. Quaternary Science Reviews 19, 1233-1253.

Irwin RP, Howard AD and Maxwell TA (2004) Geomorphology of Ma'adim Vallis, Mars, and associated paleolake basins. Journal of Geophysical Research: Planets 109(E12).

Kanevskiy M, Shur Y, Fortier D, Jorgenson MT and Stephani E (2011) Cryostratigraph of late Pleistocene syngenetic permafrost (yedoma) in northern Alaska, Itkillik River exposure. Quaternary Research 75 584-596.

Keisling BA, Nielsen LT, Hvidberg CS, Nuterman R and DeConto RM (2020) Plio-Pleistocene megafloods as a mechanism for Greenlandic megacanyon formation. Geology 48(7), 737-741.

Kelly S (2006) Scaling and hierarchy in braided rivers and their deposits: examples and implications for reservoir modelling. In Sambrook Smith GH, Best JL, Bristow CS and Petts GE (eds), Braided Rivers: Process, Deposits, Ecology and Management. International Association of Sedimentologists, Blackwell Publishing, vol. 36, pp. 75-106.

Klausen TG, Nyberg B and Helland-Hansen W (2019) The largest delta plain in earth's history. Geology 47, 470-474.

Kleiven HFK and 5 others (2008) Reduced North Atlantic deep water coeval with the Glacial Lake Agassiz freshwater outburst. Science 319, 60-64.

Knies J and 9 others (2009) The Plio-Pleistocene glaciation of the Barents Sea-Svalbard region: a new model based on revised chronostratigraphy. Quaternary Science Reviews 28, 812-829.

Knighton D (1998) Fluvial Forms and Processes: A New Perspective. Taylor and Francis Ltd, Routledge, 2nd revised Edn, $400 \mathrm{pp}$.

Komar P (1979) Comparisons of the hydraulics of water flows in the Martian outflow channels with flows of similar scale on Earth. Icarus 37, 156-181.

Ktenas D, Meisingset I, Henriksen E and Nielsen JK (2019) Estimation of net apparent erosion in the SW Barents Sea by applying velocity inversion analysis. Petroleum Geoscience 25(2), 169-187.

Laberg JS, Andreassen K and Vorren TO (2010) Late Cenozoic erosion of the high-latitude southwestern Barents Sea shelf revisited. GSA Bulletin 124 $77-88$

Laberg JS and Vorren TO (1996) The middle and late Pleistocene evolution and the bear Island trough mouth fan. Global and Planetary Change $\mathbf{1 2}$ 309-330.

Larsen IJ and Lamb MP (2016) Progressive incision of the channeled scablands by outburst floods. Nature 538, 229-232.

Lebedeva-Ivanova $\mathbf{N}$ and 5 others (2018) Towards One-meter resolution in 3D seismic. The Leading Edge 37, 818-828.

Lewis AR, Marchant DR, Kowalewski DE, Baldwin SL and Webb LE (2006) The age and origin of the Labyrinth, western Dry Valleys, Antarctica: evidence for extensive middle Miocene subglacial floods and freshwater discharge to the Southern Ocean. Geology 34(7), 513-516.

Lewis SM and Smith, LC (2009) Hydrologic drainage of the Greenland ice sheet. Hydrological Processes: An International Journal 23(14), 2004-2011.

Lind S, Ingvaldsen RB and Furevik T (2018) Arctic Warming hotspot in the northern Barents Sea linked to declining sea-ice import. Nature climate change 8(7), 634-639.

Livingstone S and 5 others (2013) Glacial geomorphology of Marguerite Bay palaeo-ice stream, western Antarctic Peninsula. Journal of Maps 9(4), $558-572$.

Lowe AL and Anderson JB (2003) Evidence for abundant subglacial meltwater beneath the paleo-ice sheet in Pine Island Bay, Antarctica. Journal of Glaciology 49, 125-138.

MacKie E, Schroeder DM, Caers J, Siegfried MR and Scheidt C (2020) Antarctic topographic realizations and geostatistical modeling used to map subglacial lakes. Journal of Geophysical Research: Earth Surface 125 (3), e2019JF005420.

Mayo LR (1988) Advance of Hubbard Glacier and closure of Russell Fiord, Alaska - Environmental effects and hazards in the Yakutal area. U.S Geological Survey Circular 1016, 4-16.

Meinsen J and 5 others (2011) Middle Pleistocene (Saalian) lake outburst floods in the Münsterland Embayment (NW Germany): impacts and magnitudes. Quaternary Science Reviews 30, 2597-2625.

Miall AD (1977) A review of the braided-river depositional environment. Earth-Science Reviews 13, 1-62.
Morlighem M and 31 others (2017) Bedmachine v3: complete bed topography and ocean bathymetry mapping of Greenland from multibeam echo sounding combined with mass conservation. Geophysical Research Letters 44, 11051-11061.

Munoz YP and Wellner JS (2018) Seafloor geomorphology of western Antarctic Peninsula bays: a signature of ice flow behavior. The Cryosphere 12, 205-225.

Munro-Stasiuk MJ and 8 others (2009) 6 The morphology and sedimentology of landforms created by subglacial megafloods. Megaflooding on Earth and Mars 78, 78-103.

Murton JB, Bateman MD, Dallimore SR, Teller JT and Yang Z (2010) Identification of Younger Dryas outburst flood path from Lake Agassiz to the Arctic Ocean. Nature 464, 740-743.

Newton AMW and Huuse M (2017) Glacial geomorphology of the central Barents Sea: implications for the dynamic deglaciation of the Barents Sea Ice Sheet. Marine Geology 387, 114-131.

Ó Cofaigh C (1996) Tunnel valley genesis. Progress in Physical Geography 20, $1-19$.

O'Connor JE and 6 others (2020) The Missoula and Bonneville floods - A review of ice-age megafloods in the Columbia River basin. Earth-Science Reviews 208, 103181.

O'Connor JE and Baker VR (1992) Magnitudes and implications of peak discharges from glacial Lake Missoula. Geological Society of America Bulletin 104(3), 267-279.

Ottesen D, Rise L, Knies J, Olsen L and Henriksen S (2005) The VestfjordenTrænadjupet palaeo-ice stream drainage system, mid-Norwegian continental shelf. Marine Geology 218, 175-189.

Patton H, Hubbard A, Andreassen K, Winsborrow M and Stroeven AP (2016) The build-up and dynamical sensitivity of the Eurasian ice-sheet complex to Late Weichselian climatic and oceanic forcing. Quaternary Science Reviews 153, 97-121.

Piasecka ED, Winsborrow MCM, Andreassen K and Stokes CR (2016) Reconstructing the retreat dynamics of the Bjørnøyrenna Ice Stream based on new 3D seismic data from the central Barents Sea. Quaternary Science Reviews 151, 212-227.

Piotrowski JA (1994) Tunnel-valley formation in northwest Germany - geology, mechanisms of formation and subglacial bed conditions for the Bornhöved tunnel valley. Sedimentary Geology 89, 107-141.

Planke S and 5 others (2017) Igneous seismic geomorphology of buried lava fields and coastal escarpments on the Vøring volcanic rifted margin. Interpretation 5(3), 161-177.

Posamentier HW (2001) Lowstand alluvial bypass systems: incised vs. unincised. AAPG Bulletin 85, 1771-1793.

Posamentier HW, Davies RJ, Cartwright JA and Wood L (2007) Seismic geomorphology - an overview. Geological Society, London, Special Publications 277, 1-14.

Prestes YO, da Costa Borba TA, da Silva AC and Rollnic M (2020) A discharge stationary model for the Para-Amazon estuarine system. Journal of Hydrology: Regional Studies 28, 100668.

Reinardy BTI, Hjelstuen BO, Sejrup HP, Augedal H and Jørstad A (2017) Late Pliocene-Pleistocene environments and glacial history of the northern North Sea. Quaternary Science Reviews 158, 107-126.

Rennermalm AK and 5 others (2012) Proglacial river stage, discharge, and temperature datasets from the Akuliarusiarsuup Kuua River northern tributary, Southwest Greenland, 2008-2011. Earth System Science Data 4, 1-12.

Richardson SD and Reynolds JM (2000) An overview of glacial hazards in the Himalayas. Quaternary International 65/66, 31-47.

Roberts MJ (2005) Jökulhlaups: a reassessment of floodwater flow through glaciers. Reviews of Geophysics 43(1).

Robinson MS and Tanaka KL (1990) Magnitude of a catastrophic flood event at Kasei Vallis, Mars. Geology 18, 902-905.

Rudoy AN (2012) Glacier-dammed lakes and geological work of glacial superfloods in the Late Pleistocene, Southern Siberia, Altai Mountains. Quaternary International 87, 119-140.

Russell AJ, Gregory AR, Large AR, Fleisher PJ and Harris TD (2007) Tunnel channel formation during the November 1996 jökulhlaup, Skeiðarárjökull, Iceland. Annals of Glaciology 45, 95-103.

Russell AJ, van Tatenhove FG and van de Wal RS (1995) Effects of ice-front collapse and flood generation on a proglacial river channel near kangerlussuaq (Søndre Strømfjord), west Greenland. Hydrological Processes 9(2), 213-226.

Rust BR (1972) Structure and process in a braided river. Sedimentology 18, $221-245$ 
Rüther D, Andreassen K and Spagnolo M (2013) Aligned glaciotectonic rafts on the central Barents Sea seafloor revealing extensive glacitectonic erosion during the last deglaciation. Geophysical Research Letters 40(24), 6351-6355.

Schirrmeister L, Froese D, Tumskoy V, Grosse G and Wetterich S (2013) Yedoma: late pleistocene ice-rich syngenetic permafrost of Beringia. Encyclopedia of Quaternary Science, 2nd Edn. Elsevier, pp. 542-552.

Schumm SA (1985) Patterns of alluvial rivers. Annual Review of Earth and Planetary Sciences 13, 5-27.

Schumm S and Kahn H (1972) Experimental study of channel patterns. Bulletin of the Geological Society of America 83, 1755-1770.

Sejrup HP and 5 others (2005) Pleistocene glacial history of the NW European continental margin. Marine and Petroleum Geology 22, 1111-1129.

Shackleton C and 7 others (2018) Subglacial water storage and drainage beneath the Fennoscandian and Barents Sea ice sheets. Quaternary Science Reviews 201, 13-28.

Shugar DH and 9 others (2020) Rapid worldwide growth of glacial lakes since 1990. Nature Climate Change 10(10), 939-945.

Siegfried MR and Fricker HA (2018) Thirteen years of subglacial lake activity in Antarctica from multi-mission satellite altimetry. Annals of Glaciology $\mathbf{5 9}$ (76pt1), 42-55.

Simkins LM and 8 others (2017) Anatomy of a meltwater discharge system beneath the ancestral East Antarctic ice sheet. Nature Geoscience 10, 691-697.

Sjogren DB and Rains RB (1995) Glaciofluvial erosional morphology and sediments of the coronation-Spondin Scabland, east-central Alberta. Canadian Journal of Earth Sciences 32(5), 565-578.

Smith GA (1993) Missoula flood dynamics and magnitudes inferred from sedimentology of slack-water deposits on the Columbia Plateau, Washington. Geological Society of America Bulletin 105, 77-100.

Smith DG and Fisher TG (1993) Glacial Lake Agassiz: the northwestern outlet and paleoflood. Geology 21, 9-12.

Smith DP, Kvitek R, Iampietro PJ and Wong K (2007) Twenty-nine months of geomorphic change in upper Moneterey Canyon (2002-2005). Marine Geology 236, 79-94.

Snorrason Á and 6 others (2002) November 1996 Jökulhlaup on skeiðarársandur outwash plain, Iceland. Flood and Megaflood Processes and Deposits: Recent and Ancient Examples, Wiley Online Library, pp. 53-65.

Stackebrandt W (2009) Subglacial channels of Northern Germany - a brief review. Zeitschrift der Deutschen Gesellschaft für Geowissenschaften 160, 203-210.

Stewart MA, Lonergan L and Hampson G (2013) 3D Seismic analysis of buried tunnel valleys in the central North Sea: morphology, cross-cutting generations and glacial history. Quaternary Science Reviews 72, 1-17.
Stott T (2002) Bedload transport and channel bed changes in the proglacial Skeldal River, northeast Greenland. Arctic, Antarctic, and Alpine Research 34(3), 334-345.

Stott TA and Grove JR (2001) Short-term discharge and suspended sediment fluctuations in the proglacial Skeldal River, north-east Greenland. Hydrological Processes 15(3), 407-423.

Sættem J, Poole DAR, Ellingsen L and Sejrup HP (1992) Glacial geology of outer Bjørnøyrenna, southwestern Barents Sea. Marine Geology 103 15-51.

Sugden D and Denton G (2004) Cenozoic landscape evolution of the Convoy Range to Mackay Glacier area, transantarctic Mountains: onshore to offshore synthesis. Geological Society of America Bulletin 116(7-8), 840-857.

Svendsen JI and 29 others (2004) Late Quaternary ice sheet history of northern Eurasia. Quaternary Science Reviews 23(11-13), 1229-1271.

Tasianas A and 6 others (2018) High-resolution 3D seismic study of pockmarks and shallow fluid flow systems at the Snøhvit hydrocarbon field in the SW Barents Sea. Marine Geology 403, 247-261.

Teller JT, Leverington DW and Mann JD (2002) Freshwater outbursts to the oceans from glacial Lake Agassiz and their role in climate change during the last deglaciation. Quaternary Science Reviews 21, 879-887.

van den Berg JH (1995) Prediction of alluvial channel pattern of perennial rivers. Geomorphology 12, 259-279.

Vorren TO, Richardsen G, Knutsen SM and Henriksen E (1991) Cenozoic erosion and sedimentation in the western Barents Sea. Marine and Petroleum Geology 8, 317-340.

Wiedmer M, Montgomery DR, Gillespie AR and Greenberg H (2010) The quaternary megafloods from Glacial Lake Atna, Southcentral Alaska, U.S.A. Quaternary Research 73, 413-424.

Willis IC, Richards KS and Sharp MJ (1996) Links between proglacial stream suspended sediment dynamics, glacier hydrology and glacier motion at Midtdalsbreen, Norway. Hydrological Processes 10, 629-648.

Wingham DJ, Siegert MJ, Shepherd A and Muir AS (2006) Rapid discharge connects Antarctic subglacial lakes. Nature 440(7087), 1033-1036.

Winsborrow MCM, Andreassen K, Corner CD and Laberg JS (2010) Deglaciation of a marine-based ice sheet: Late Weichselian palaeo-ice dynamics and retreat in the southern Barents Sea reconstructed from onshore and offshore glacial geomorphology. Quaternary Science Reviews 29, 424-442.

Wright A and Siegert M (2012) A fourth inventory of Antarctic subglacial lakes. Antarctic Science 24(6), 659.

www.npd.no (2018) Norwegian Petroleum Directorate (NPD), Stavanger, Norway, 18.09.2018. Factpages of exploration wellbores. [online]. http://fact pages.npd.no/factpages/. 